\title{
Different ocean states and transient characteristics in Last Glacial Maximum simulations and implications for deglaciation
}

\author{
X. Zhang, G. Lohmann, G. Knorr, and X. Xu \\ Alfred Wegener Institute Helmholtz Centre for Polar and Marine Research, Bussestrasse 24, 27570 Bremerhaven, Germany \\ Correspondence to: X. Zhang (xu.zhang@awi.de)
}

Received: 6 July 2012 - Published in Clim. Past Discuss.: 1 August 2012

Revised: 5 July 2013 - Accepted: 13 August 2013 - Published: 15 October 2013

\begin{abstract}
The last deglaciation is one of the best constrained global-scale climate changes documented by climate archives. Nevertheless, understanding of the underlying dynamics is still limited, especially with respect to abrupt climate shifts and associated changes in the Atlantic meridional overturning circulation (AMOC) during glacial and deglacial periods. A fundamental issue is how to obtain an appropriate climate state at the Last Glacial Maximum (LGM, $21000 \mathrm{yr}$ before present, $21 \mathrm{ka} \mathrm{BP}$ ) that can be used as an initial condition for deglaciation. With the aid of a comprehensive climate model, we found that initial ocean states play an important role on the equilibrium timescale of the simulated glacial ocean. Independent of the initialization, the climatological surface characteristics are similar and quasi-stationary, even when trends in the deep ocean are still significant, which provides an explanation for the large spread of simulated LGM ocean states among the Paleoclimate Modeling Intercomparison Project phase 2 (PMIP2) models. Accordingly, we emphasize that caution must be taken when alleged quasistationary states, inferred on the basis of surface properties, are used as a reference for both model inter-comparison and data model comparison.

The simulated ocean state with the most realistic AMOC is characterized by a pronounced vertical stratification, in line with reconstructions. Hosing experiments further suggest that the response of the glacial ocean is dependent on the ocean background state, i.e. only the state with robust stratification shows an overshoot behavior in the North Atlantic. We propose that the salinity stratification represents a key control on the AMOC pattern and its transient response to perturbations. Furthermore, additional experiments suggest that the stratified deep ocean formed prior to the LGM during a time of minimum obliquity ( $\sim 27 \mathrm{ka} \mathrm{BP})$. This indicates
\end{abstract}

that changes in the glacial deep ocean already occur before the last deglaciation. In combination, these findings represent a new paradigm for the LGM and the last deglaciation, which challenges the conventional evaluation of glacial and deglacial AMOC changes based on an ocean state derived from $21 \mathrm{ka}$ BP boundary conditions.

\section{Introduction}

Due to its capability to redistribute large amounts of heat around the globe (e.g. Ganachaud and Wunsch, 2000), the Atlantic meridional overturning circulation (AMOC) is a key player in the global climate system. Potential changes in the operational mode of the AMOC, as a consequence of alterations in the hydrological cycle and greenhouse gas concentration, draw our concerns regarding the future fate of our climate (Meehl et al., 2007).

During glacial and deglacial periods, large and abrupt changes in the climate system are thought to have repeatedly occurred. These changes have been linked to large and abrupt shifts in the AMOC (e.g. Dansgaard et al., 1993; Bard et al., 2000; Ganopolski and Rahmstorf, 2001; Knorr and Lohmann, 2003, 2007; Liu et al., 2009; Barker et al., 2010; Menviel et al., 2011). A well-suited period to investigate the underlying mechanisms by model simulations is the last deglaciation (Knorr and Lohmann, 2007; Liu et al., 2009; Menviel et al., 2011) due to the abundance of available data based reconstructions (e.g. Lea et al., 2003; McManus et al., 2004; Peltier, 2004; Ahn and Brook, 2008; Gherardi et al., 2009). One of the most fundamental issues in this respect is the definition of a climate state to be used as an initial state. On account of the abundance of 
available proxy data and maximum ice sheet volume (Duplessy et al., 1988; Bard et al., 2000; Adkins et al., 2002; Pflaumann, 2003; Peltier, 2004; Gersonde et al., 2005; LynchStieglitz et al., 2007; Clark et al., 2009; Gutjahr and Lippold, 2011; Hesse et al., 2011), the Last Glacial Maximum (LGM, about $21000 \mathrm{yr}$ before present, hereafter $21 \mathrm{kaBP}$ ) commonly serves as the starting point for simulations of the last deglaciation (Liu et al., 2009; Menviel et al., 2011). Furthermore, it is also an excellent test bed for climate models to simulate a climate that strongly deviates from our modern condition (e.g. the Paleoclimate Modeling Intercomparison Projection, or PMIP; Braconnot et al., 2007) for the future projection (Braconnot et al., 2012). However, there was a substantial difference in AMOC states among different models during the LGM (Otto-Bliesner et al., 2007). It is worth noting that PMIP utilized no specific protocol concerning the initial ocean condition for LGM simulations, and only CCSM3 and HadCM3M2, initialized from a previous glacial ocean state, were found to yield a simulated glacial ocean comparable to reconstructions (Fig. 1) (Braconnot et al., 2007; Weber et al., 2007). Thus, it is open to question whether the different LGM AMOC states are potentially associated with different regimes due to the mean deep-ocean properties. Following this, we further elaborate the transient responses upon different background conditions.

\section{Model and experimental design}

\subsection{Model description}

The comprehensive climate model COSMOS (ECHAM5JSBACH-MPIOM) is used to analyse the different responses of the LGM to initial ocean states. The atmosphere model ECHAM5 (Roeckner et al., 2003), complemented by land surface model JSBACH (Brovkin et al., 2009), was used at T31 resolution $\left(\sim 3.75^{\circ}\right)$ with 19 vertical layers. The ocean model MPI-OM (Marsland et al., 2003), including the dynamics of sea ice formulated using viscous-plastic rheology (Hibler III, 1979), has the resolution of GR30 $\left(\sim 3^{\circ}\right)$ in the horizontal and 40 uneven vertical layers. Note that the Hydrological Discharge model (HDmodel) (Hagemann, 2002) is also embedded in the ECHAM5, guaranteeing a closure freshwater balance in our coupled system. The climate model was already utilized to analyse the last millennium (Jungclaus et al., 2010), warm climates in the Miocene (Knorr et al., 2011) and the Pliocene (Stepanek and Lohmann, 2012; Dowset et al., 2013), glacial (Kageyama et al., 2013; Gong et al., 2013) and interglacial climate (Varma et al., 2012; Wei et al., 2012; Wei and Lohmann, 2012).

\subsection{Experimental design}

In the following section we describe the experimental set-up of the ten model simulations that represent the basis for our
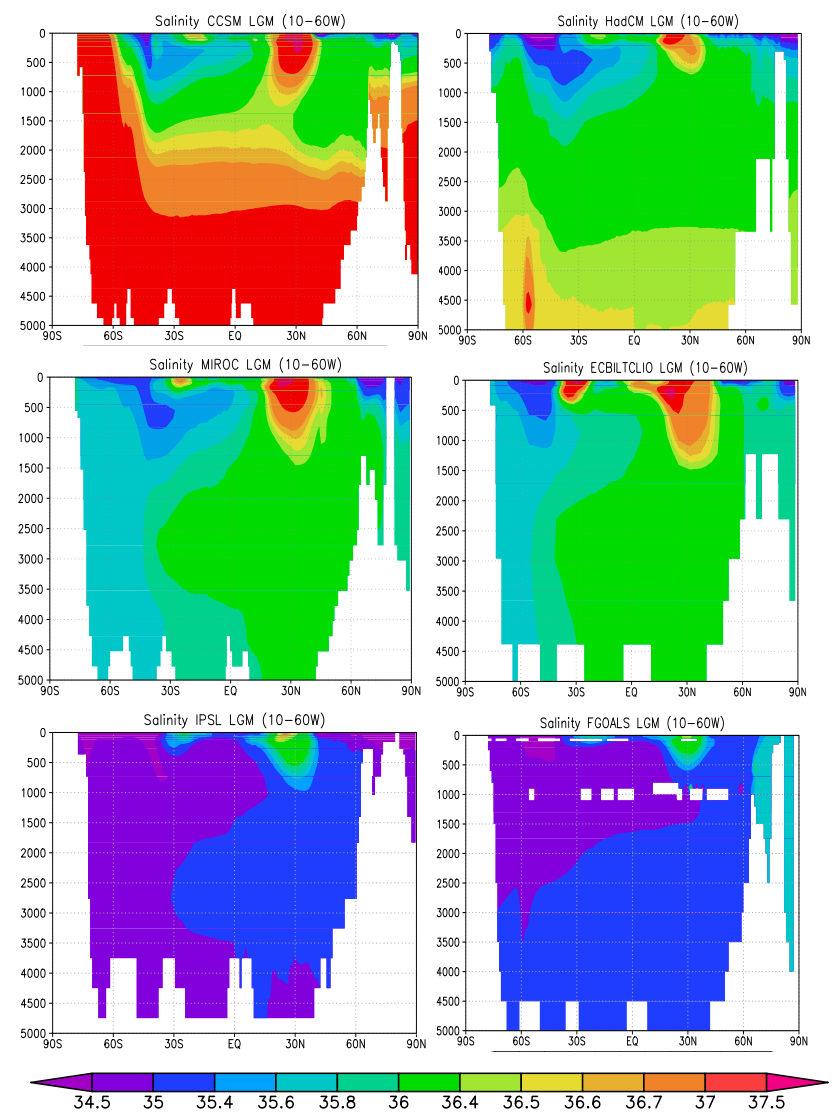

Fig. 1. Meridional section of zonal mean salinity in Atlantic Ocean for six PMIP2 models (CCSM3 (Otto-Bliesner et al., 2007) HadCM3M2 (Gordon et al., 2000), MIROC 3.2 (K-1-ModelDevelopers, 2004), ECBilt-CLIO (de Vries and Weber, 2005), FGOALS-1.0g (Yu et al., 2002, 2004) and IPSL-CM4-V1-MR (Marti et al., 2005)). The stratification in CCSM3 and HadCM3M2 is comparable with reconstruction (Otto-Bliesner et al., 2007), while the ocean structure in MIROC 3.2, ECBilt-CLIO, FGOALS$1.0 \mathrm{~g}$ and IPSL-CM4-V1-MR is more like the present-day, with the saltiest deep-water mass in the North Atlantic. According to their salinity structure, one can divide the PMIP2 models into two main classes, which are related to a highly stratified ocean, but weaker AMOC (i.e. CCSM3 and HadCM, as our quasi-equilibrium ocean state) and weaker stratified, but stronger AMOC (transient ocean state).

study. A summary of the experiment characteristics is also provided in Table 1.

\subsubsection{LGM simulations}

External forcing and boundary conditions are imposed according to the PMIP3 protocol for the LGM (available at http://pmip3.lsce.ipsl.fr/). The respective boundary conditions for the LGM comprise orbital forcing, greenhouse gas concentrations $\left(\mathrm{CO}_{2}=185 \mathrm{ppm} ; \mathrm{N}_{2} \mathrm{O}=200 \mathrm{ppb} ; \mathrm{CH}_{4}=\right.$ $350 \mathrm{ppb}$ ), ocean bathymetry, land surface topography, runoff routes according to PMIP3 ice sheet reconstruction and 
Table 1. Experimental design of the simulations in this study.

\begin{tabular}{lllc}
\hline & Boundary conditions & Initial conditions & $\begin{array}{c}\text { Integration } \\
\text { of model years }\end{array}$ \\
\hline PI (control) & Pre-industrial & Present-day ocean & 3000 \\
LGM2PI & Pre-Industrial & Glacial ocean & 3000 \\
LGMW & $21 \mathrm{ka}$ & Glacial ocean & 4000 \\
LGMS & $21 \mathrm{ka}$ & Present-day ocean & 5000 \\
\hline LGMS27ka & $21 \mathrm{ka}$, except 27 ka & model year 4000 in LGMS & 700 \\
& orbital forcing & & 150 \\
\hline LGMW-0.2Sv & $21 \mathrm{ka}$ & LGMW-e (model year 2900 in LGMW) & 100 \\
LGMW-1Sv & $21 \mathrm{ka}$ & LGMW-e (model year 2900 in LGMW) & 150 \\
LGMS-0.2Sv & $21 \mathrm{ka}$ & LGMS-t & 100 \\
LGMS-1Sv & $21 \mathrm{ka}$ & LGMS-t deep (model year 2900 in LGMS) & 150 \\
LGMS-e-0.2Sv & $21 \mathrm{ka}$ & LGMS-e (model year 4600 in LGMS) & 1000 in LGMS) \\
\hline
\end{tabular}

increased global salinity ( +1 psu compared to modern value) to account for a sea level drop of $\sim 116 \mathrm{~m}$.

Using the same LGM boundary conditions we performed two experiments, LGMW and LGMS, with different initial ocean states and integrated them for 4000 and $5000 \mathrm{yr}$, respectively. LGMS is initialized from a ocean state with imposed present-day temperature and salinity fields (Levitus et al., 1998), while LGMW is initialized from a glacial ocean state. The initial glacial ocean was generated through an ocean-only model, MPI-OM (ocean component of our COSMOS set-up), which was run for $3000 \mathrm{yr}$ under the LGM conditions. To generate the glacial ocean state with MPI-OM, we obtained its atmospheric forcing from an ECHAM5 experiment in T31 resolution using SST forcing as provided by CLIMAP (CLIMAP, 1981) in a similar way as done with the older ECHAM3 version (Lohmann and Lorenz, 2000), and derived its initial ocean state and surface salinity restoring from PMIP2 model outputs of CCSM3 (the National Center for Atmospheric Research CCSM3 model) that is assumed to have a good performance on simulating the LGM climate state in comparison to other PMIP2 models (Otto-Bliesner et al., 2007; Weber et al., 2007).

To define the representative climatology from both LGM runs we employed the quasi-equilibrium criteria of the PMIP protocol (Braconnot et al., 2007) to assess the stability of the simulated ocean states. That is, quasi-equilibrium state can be defined, as the global SST trend is less than 0.05 k century $^{-1}$ as well as a stable AMOC. Figures 2 and 3 show the AMOC indices and $100 \mathrm{yr}$ running means of global mean sea surface temperature (SST) for the simulations LGMW and LGMS. Compared to the gradual increase of AMOC and SST in LGMW, the decreasing trend in LGMS is particularly pronounced, especially after the model year 3000 .

Based on the PMIP criteria (Braconnot et al., 2007), LGMW and LGMS are in quasi-equilibrium after model years 2700 and 4500, respectively. In LGMW, due to the fact that there is almost no change in the climatology after model year 2700 (Figs. 2-7 and S2), the climatologically annual mean of model years 2900-3000 was chosen to represent the quasi-equilibrium ocean state LGMW-e. In LGMS, there is almost no difference between climatology of model years 4600-4700 and 4500-5000. To better compare with the outputs from the $27 \mathrm{ka}$ simulation (see details in Sect. 2.2.4), thus we define the climatology mean between model years 4600-4700 as LGMS-e to represent the quasi-equilibrium state in LGMS.

Note that the ocean state between model years 2500-3000 in LGMS also meets PMIP criteria (Fig. S1, for a zoomin plot of AMOC indices and global mean SST), although the trend in its deep ocean properties is significant (Fig. 4). Accordingly, to better compare with LGMW-e, model years 2900-3000 in LGMS are averaged to represent this ocean state and named as LGMS- $t_{\text {deep }}$ here.

A comparison among the ocean states LGMS- $t_{\text {deep }}$, LGMS-e and LGMW-e was made with respect to the corresponding climatology (Figs. 5-7 and S2) and surface and deep ocean trends (Figs. 2-4). It suggests that due to their similarity LGMS-e and LGMW-e can represent the final equilibrium LGM state in our model, however LGMS- $t_{\text {deep }}$ is the state in the transient phase of bottom-water properties. In this study, we will mainly focus on the contrast between LGMS- $t_{\text {deep }}$ and LGMW-e (Figs. 2-4).

\subsubsection{Pre-industrial simulations}

To examine whether the feature of time-dependency on initial ocean states in glacial simulations is also present in a warm climate, we conducted two pre-industrial (PI) simulations in this study. One was initialized from the same presentday ocean state as LGMS, which is referred to as PI control run and has been analyzed by Wei et al. (2012). The other one, LGM2PI, was initialised from the glacial ocean state of 

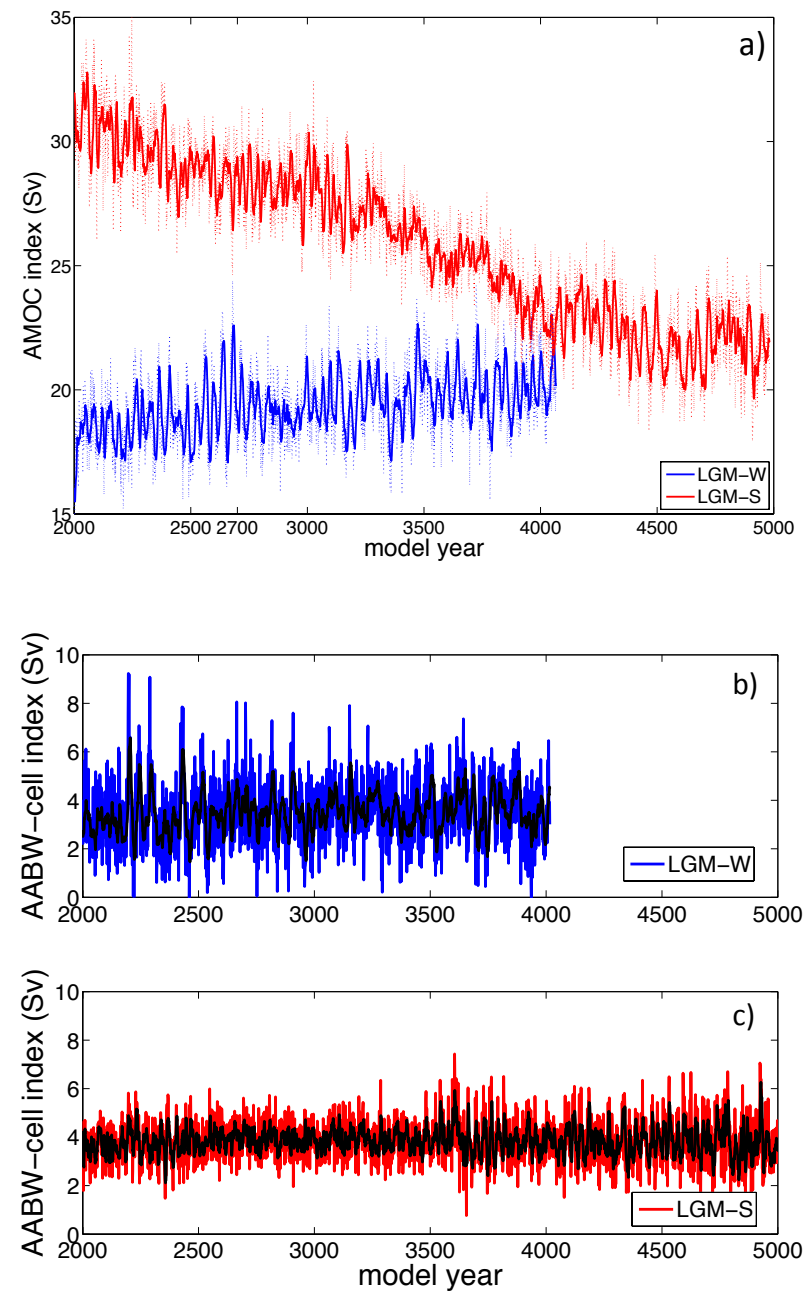

Fig. 2. AMOC indices with respect to (a) NADW-cell (defined as the maximum value of stream function below $500 \mathrm{~m}$ in the North Atlantic) and (b-c) AABW-cell (defined as the maximum of absolute value of stream function below $2500 \mathrm{~m}$ along $30^{\circ} \mathrm{S}$ ) for LGMS (red) and LGMW (blue). The bold solid lines are the $10 \mathrm{yr}$ running mean. Units: $\mathrm{Sv}=10^{6} \mathrm{~m}^{3} \mathrm{~s}^{-1}$.

LGMW. Both PI simulations were integrated for $3000 \mathrm{yr}$ (Table 1) using identical PI boundary conditions as in previous studies in PMIP (Crucifix et al., 2005). The average of the model years $2900-3000$ is considered to represent the climatology in both simulations.

\subsubsection{Hosing experiments}

To investigate the stability of the two LGM ocean states and the dependence of the AMOC on ocean stratification, we have imposed constant freshwater perturbations (FWP) of $+0.2 \mathrm{~Sv}$ and $+1 \mathrm{~Sv}$ over the Ice-Rafted Debris belt (around $40^{\circ} \mathrm{N}-55^{\circ} \mathrm{N}, 45^{\circ} \mathrm{W}-20^{\circ} \mathrm{W}$ ) (Hemming, 2004) in the North Atlantic for 150 and $100 \mathrm{yr}$, respectively (Table 1). After the FWP, the experiments continued running for another $250 \mathrm{yr}$ to evaluate the recovery processes.

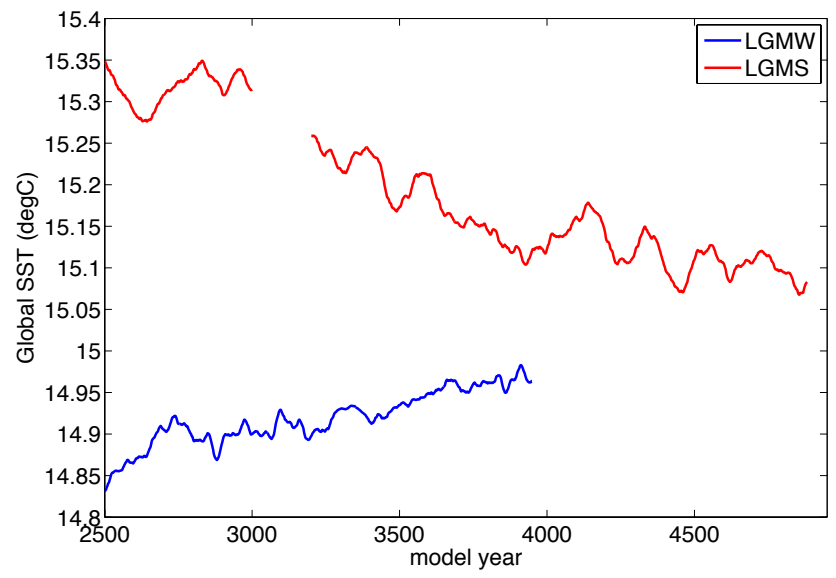

Fig. 3. $100 \mathrm{yr}$ running mean for global mean SST in LGMW (blue) and LGMS (red). The gap between the model year 3000-3200 in LGMS is due to missed dataset. Units: ${ }^{\circ} \mathrm{C}$.

\subsubsection{The 27 ka simulation}

As explicitly discussed in Sect. 3.2, reconstructions suggest that the recorded LGM ocean structure might have been formed prior to the LGM. To gain a deeper understanding on the influence of boundary conditions (especially insolation) in shaping the state of the LGM ocean and AMOC, we performed the simulation LGMS27ka in which orbital parameters of $27 \mathrm{ka} \mathrm{BP}$ (precession: $196.532^{\circ}$, obliquity: $22.2514^{\circ}$, eccentricity: 0.017451) (Laskar et al., 2004) are imposed on LGM boundary conditions. This simulation was initialized from model year 4000 of LGMS and is integrated for $700 \mathrm{yr}$ (Table 1). The last $100 \mathrm{yr}$ average was considered to represent the corresponding $27 \mathrm{ka} \mathrm{BP}$ climatology.

\section{Results and discussion}

\subsection{Different LGM ocean states and their responses to freshwater perturbation}

\subsubsection{Surface properties}

The global climatological mean SST are $14.9^{\circ} \mathrm{C}$ and $15.3^{\circ} \mathrm{C}$ in LGMW-e and LGMS-t deep, i.e. $2.8^{\circ} \mathrm{C}$ and $2.4^{\circ} \mathrm{C}$ lower than the PI control run, respectively. The SST differences relative to PI are similar in the quasi-equilibrium ocean states (Figs. 5 and 6). In the high latitudes of the Southern Hemisphere, our model simulates a pronounced annual mean cooling of SST around Antarctica (Figs. 5 and 6), in line with proxy data (Gersonde et al., 2005). In the Northern Hemisphere, a robust meridional thermal gradient is well simulated around $40 \sim 45^{\circ} \mathrm{N}$, and the most pronounced cooling is found off the eastern coast of Iceland to eastern part of Nordic Sea (Figs. 5 and 6). Both features are comparable to reconstructions (Kucera et al., 2005; de Vernal et al., 2006). In contrast to the MARGO data (Waelbroeck et al., 2009), 

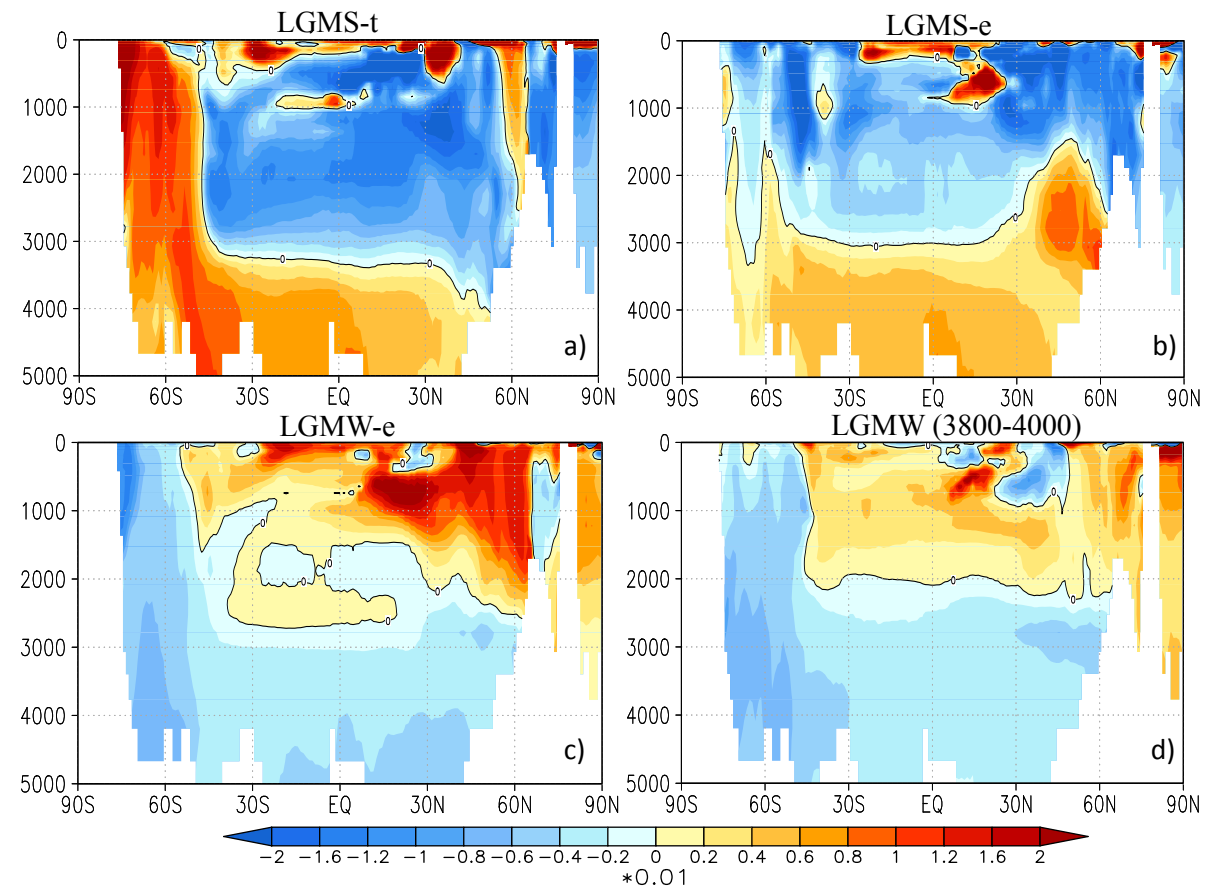

Fig. 4. Salinity trend in Atlantic Ocean for model year 2800-3000 in LGMS- $t_{\text {deep }}$ (A) and LGMW-e (C) and model year 4500-4700 in LGMS-e (B) and model year 3800-4000 in LGMW (D). Units: psu century ${ }^{-1}$.

our model as well as PMIP2 models underestimate the pronounced east-west SST anomaly gradient in the northern North Atlantic.

Despite the different initial conditions in LGMW and LGMS, there is also a reasonable agreement between the sea ice concentrations (SIC) in both ocean states and proxy data (Fig. 5a, b), such as the austral winter sea ice extent in the Atlantic sector and the austral summer sea ice extent in the Indian ocean sector (Gersonde et al., 2005). But the simulations underestimate the large extent of summer sea ice between $5^{\circ} \mathrm{E}$ and $5^{\circ} \mathrm{W}$ in the Southern Ocean. During boreal winter, sea ice increases, especially along the coast of Newfoundland, extending far into the western Atlantic (Pflaumann, 2003; Kucera et al., 2005; de Vernal et al., 2006). Sea ice extent is underestimated in the north-eastern Atlantic Ocean in our model (Paul and Schäfer-Neth, 2003; Pflaumann, 2003) due to an active North Atlantic current that maintains relatively warm conditions at the sea surface (Fig. 5). During boreal summer the eastern part of the Nordic seas is partly sea ice-free (Fig. 5a, b), which is spatially coherent with sea ice free conditions as indicated in the GLAMAP reconstruction of the LGM (Paul and Schäfer-Neth, 2003; Pflaumann, 2003). In addition, there is perennial summer sea ice extent in the west of the Nordic Sea along the eastern coast of Greenland and Labrador Sea (Fig. 5), in agreement with the reconstructions (Pflaumann, 2003; Kucera et al., 2005; de Vernal et al., 2006). In summary, the similar surface properties generated in both LGM ocean states LGMS-t deep $_{\text {and LGMW-e }}$ are consistent with the reconstructions, representing the climatological surface patterns during the LGM.

\subsubsection{Distinct deep ocean properties}

Figure 7 shows the meridional sections of zonal mean sea salinity and temperature along the Atlantic Ocean and the spatial patterns of the AMOC. In terms of the water mass properties of ocean interior there are pronounced differences

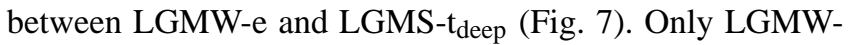
e possesses an important key feature of the glacial ocean, i.e. the saltier and colder AABW at the bottom of the Southern Ocean compared to LGMS- $t_{\text {deep }}$. This is consistent with a reconstruction of Adkins et al. (2002), while the water mass of LGMS- $t_{\text {deep }}$ is more similar to the present-day ocean state (Fig. 7e, f). According to water mass configuration reconstructed from nutrient tracers (Duplessy et al., 1988; Curry and Oppo, 2005; Marchitto and Broecker, 2006; Lynch-Stieglitz et al., 2007; Hesse et al., 2011), the North Atlantic Deep Water (NADW) shoals to about 2000-2500 m as Glacial North Atlantic Intermediate Water (GNAIW) due to the enhanced northward invasion of Antarctic Bottom Water $(\mathrm{AABW})$ at the LGM. The AMOC associated with the sinking of NADW (hereafter NADW-cell) in LGMW-e shoals by $\sim 500 \mathrm{~m}$ relative to present-day to $2500 \mathrm{~m}$. This is indicative of a shallow NADW-cell and an abyssal ocean occupied by the AABW (hereafter AABW-cell) (Fig. 7a, d, g). A similar pattern is also found in the quasi-equilibrium state LGMS-e 

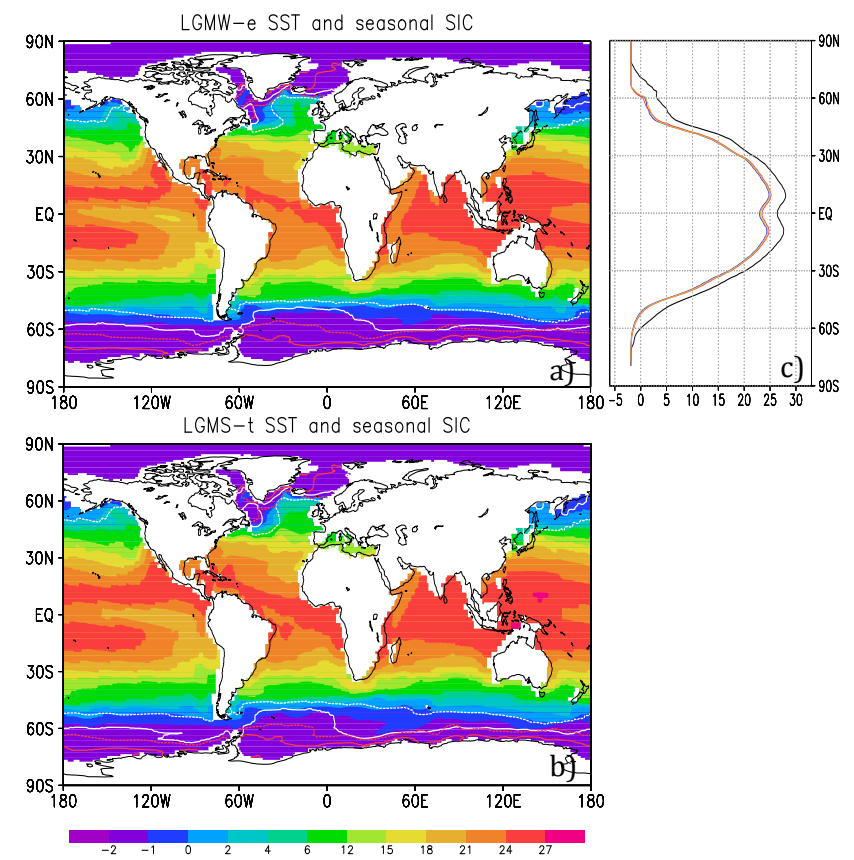

Fig. 5. Annual mean of sea surface temperature (SST, unit: ${ }^{\circ} \mathrm{C}$, shaded) and seasonal sea ice concentration (SIC, unit: \%, contour) in the LGMW-e (a) and LGMS- $t_{\text {deep }}$ (b). The white lines represent winter for each hemisphere, while the red line represents summer. The dashed lines indicate $15 \%$ SIC, and solid lines $90 \%$ SIC. (c) Zonal mean of global SST in PI (black), LGMW-e (blue) and LGMS-t $_{\text {deep }}$ (red). Units: ${ }^{\circ} \mathrm{C}$.

(Fig. S2). However, in LGMS-t $t_{\text {deep }}$ the NADW-cell penetrates to $\sim 3100 \mathrm{~m}$, even deeper than today (Fig. 7b, e, h).

Besides the evident contrast in the deep ocean properties, differences in the AMOC strength between LGMW-e and LGMS- $\mathrm{t}_{\text {deep }}$ are also pronounced, although both are stronger than present-day (Fig. 6g, h, i). In our LGM simulations, enhanced southern westerlies relative to the PI control run (Fig. S3) result in a stronger NADW-cell due to a stronger "Drake Passage Effect" via the enhanced Ekman upwelling of the deep water (Toggweiler and Samuels, 1995; Wei et al., 2012). Furthermore, stronger net evaporation in the Atlantic catchment area (Fig. S4) combined with more heat loss to the atmosphere from the convection sites over the North Atlantic (Fig. S5) also result in an enhanced NADW-cell (Weber et al., 2007). In addition, the formation of AABW as a result of brine rejection during sea ice formation is enhanced due to extensive sea ice formation and increased sea ice export during the LGM (Fig. S6) (Shin et al., 2003). As a consequence, the expected stronger AMOC states in LGMWe and LGMS- $t_{\text {deep }}$ should be distinct from today. Note that the overturning circulation is evidently reduced due to the stronger vertical stratification that weakens the AMOC from $\sim 27 \mathrm{~Sv}$ in LGMS-t $\mathrm{t}_{\text {deep }}$ (Fig. 7h) to $\sim 18 \mathrm{~Sv}$ in LGMW-e (Fig. 7g). Furthermore, the resulting AMOC in LGMW-e is also supported by reconstructions, suggesting that the glacial
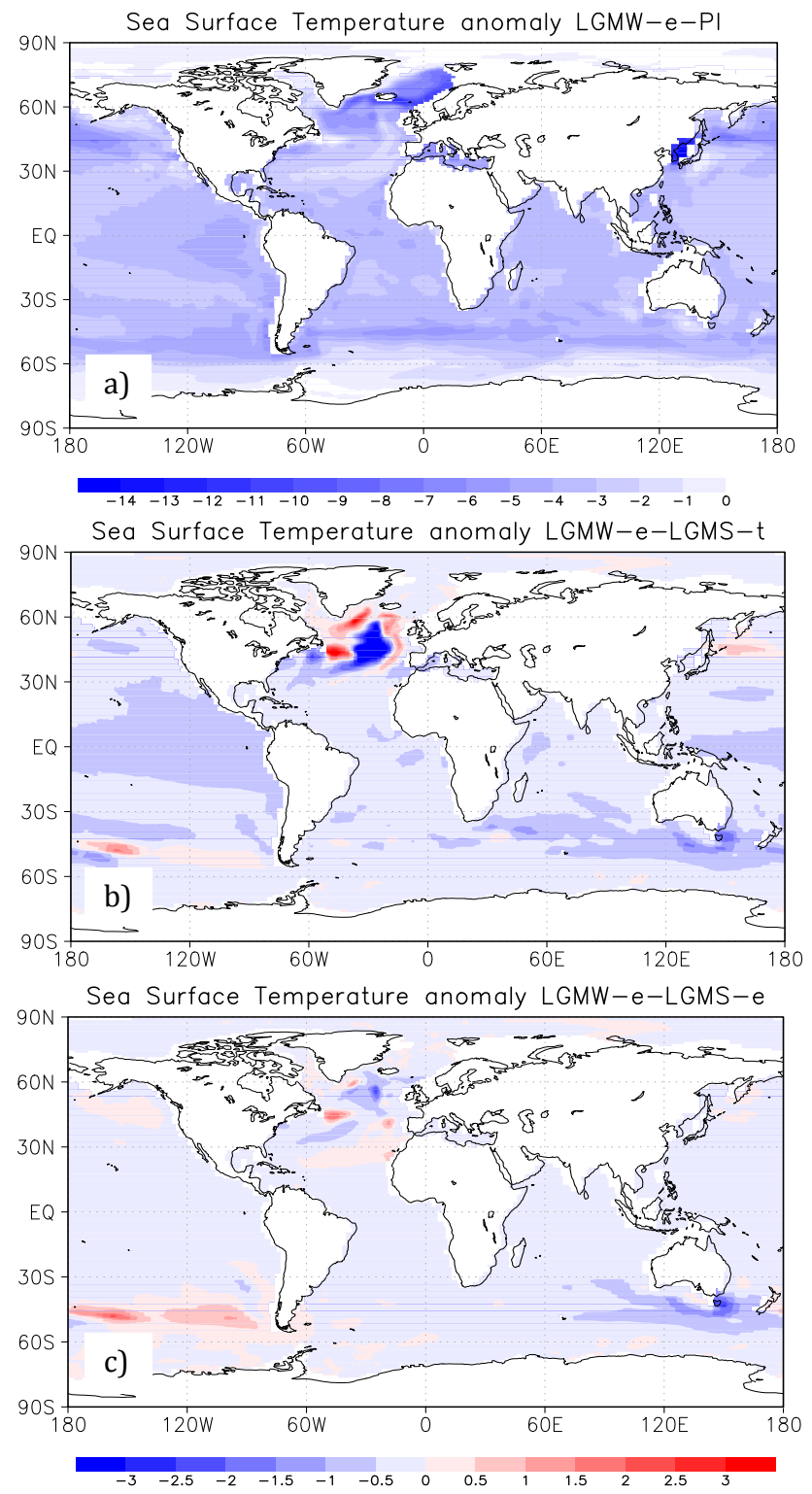

Fig. 6. Anomaly of annual mean SST for (a) LGMW-e minus PI, (b) LGMW-e minus LGMS- $t_{\text {deep }}$ and (c) LGMW-e minus LGMSe. Units: ${ }^{\circ} \mathrm{C}$.

AMOC is shallower (Duplessy et al., 1988; Curry and Oppo, 2005; Marchitto and Broecker, 2006) but as strong as in the subsequent warm periods within data uncertainties (Lippold et al., 2012; Ritz et al., 2013). Although proxy data for the LGM are actually consistent with a range of Atlantic circulation states (McCave et al., 1995; Yu et al., 1996; McManus et al., 2004; Lynch-Stieglitz et al., 2007; Praetorius et al., 2008; Gherardi et al., 2009; Huybers and Wunsch, 2010), even including the modern state (e.g., LeGrand and Wunsch, 1995), the ocean state LGMS- $t_{\text {deep }}$ can be ruled out due to its large inconsistency with the proxy data. 
a)

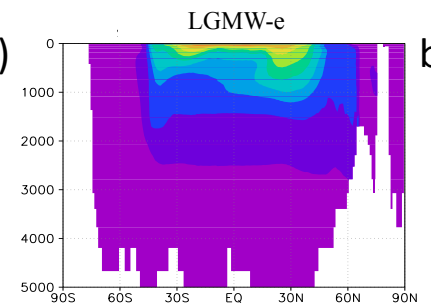

d)

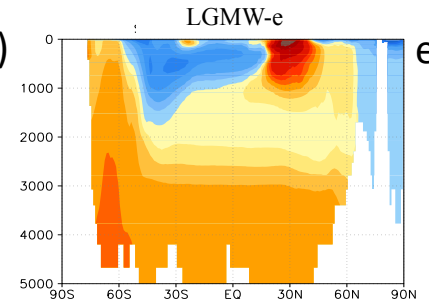

g)

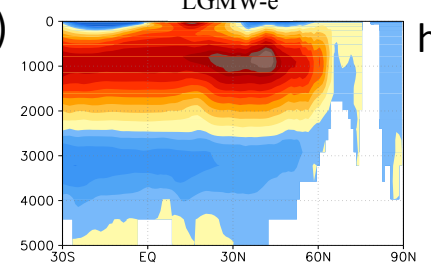

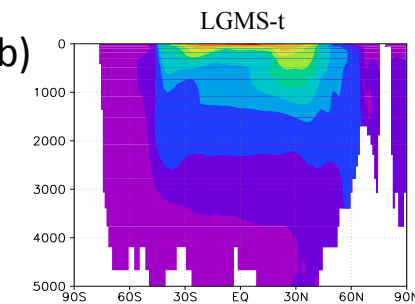
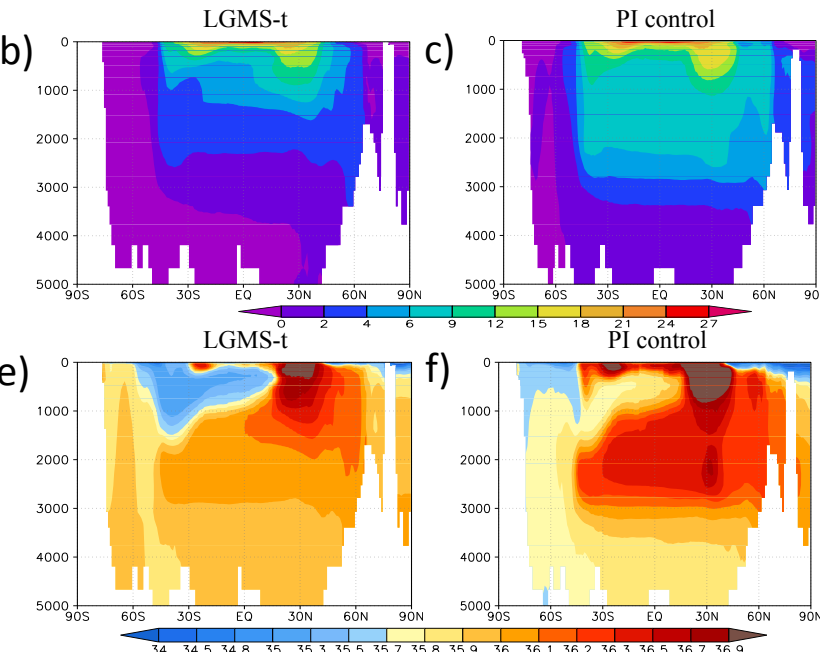

4.34 .534 .835
LGMS-t

)

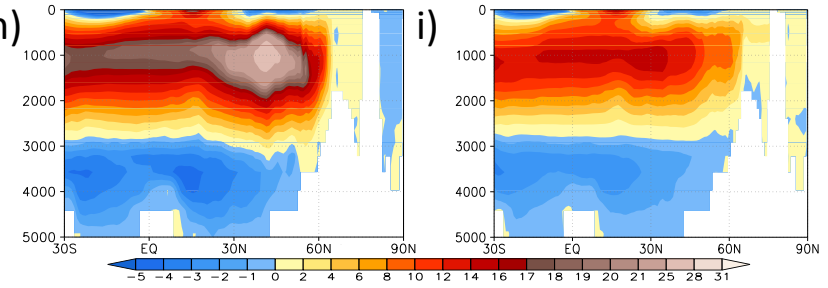

Fig. 7. Meridional section of zonal mean temperature ((A-C), units: $\left.{ }^{\circ} \mathbf{C}\right)$, salinity $((\mathbf{D}-\mathbf{F})$, units: psu) and stream function $((\mathbf{G}-\mathbf{I})$, units: Sv $\left.\left(10^{6} \mathrm{~m}^{3} \mathrm{~s}^{-1}\right)\right)$ in the Atlantic Ocean. For panel $(\mathbf{F})$, we added 1 psu to the salinity field for a better comparison with the glacial salinity structure.

The different ocean states found in our model are in quasiequilibrium according to the PMIP criteria but possess distinct features with respect to ocean structure and overturning circulation, which can be also found in PMIP2 models (Fig. 1). Accordingly, one can classify the simulated ocean states in PMIP2 models into two classes, "glacial-like" ocean state as LGMW-e and "present-day-like" glacial ocean state as LGMS- $\mathrm{t}_{\text {deep }}$.

\subsubsection{Distinct AMOC recovery processes to freshwater perturbation}

Previous model studies show a bistable regime of the AMOC in its parameter space under present climate conditions, whereby North Atlantic deep-water formation can be "on" (as in the present climate) or "off" (e.g., Rahmstorf et al., 2005). As a consequence different AMOC states can exist within the same boundary conditions, depending on the initial conditions in the ocean. In addition, transitions between different ocean states can be fulfilled by modifying the hydrological balance in the Atlantic basin, i.e. the so-called hosing experiment (e.g. Rahmstorf et al., 2005). To investigate the potential transition between ocean states LGMWe and LGMS- $\mathrm{t}_{\text {deep }}$, Fig. 8 shows the time series of AMOC indices for respective hosing experiments. It is notable that neither of these are able to trigger the transition from one ocean state to the other (Fig. 8). This implies that the reason for the different glacial ocean states is not related to the hydrological balance of the North Atlantic, but to the mean deep-ocean properties that exist due to different initial ocean conditions. After the FWP, the overshoot of the AMOC in LGMW-e (see LGMS-e case in Fig. S7) results in an abrupt warming over Greenland for several decades, but not in the LGMS- $t_{\text {deep }}$ case (Figs. 8 and 9). Given the distinct ocean structures during and after the FWP, we propose that the stratified glacial ocean plays an important role in the AMOC recovery by influencing the subsurface warming in convection sites (especially in the northern North Atlantic, Fig. S8), northward transport of tropical warmer and saltier water and basin-wide salinity adjustment (Figs. S9 and S10) (cf. Mignot et al., 2007; Liu et al., 2009; Cheng et al., 2011). This may explain the abrupt warming events over Greenland following the Heinrich events during glacial periods (e.g. the abrupt warming after Heinrich Event 2) (Dansgaard et al., 1993; Blunier and Brook, 2001).

\subsubsection{Reconciling the discrepancies in simulated LGM ocean states}

A significant feature in our LGM simulations is the different equilibrium timescales depending on the initial ocean states. When the present-day ocean serves as the initialization 

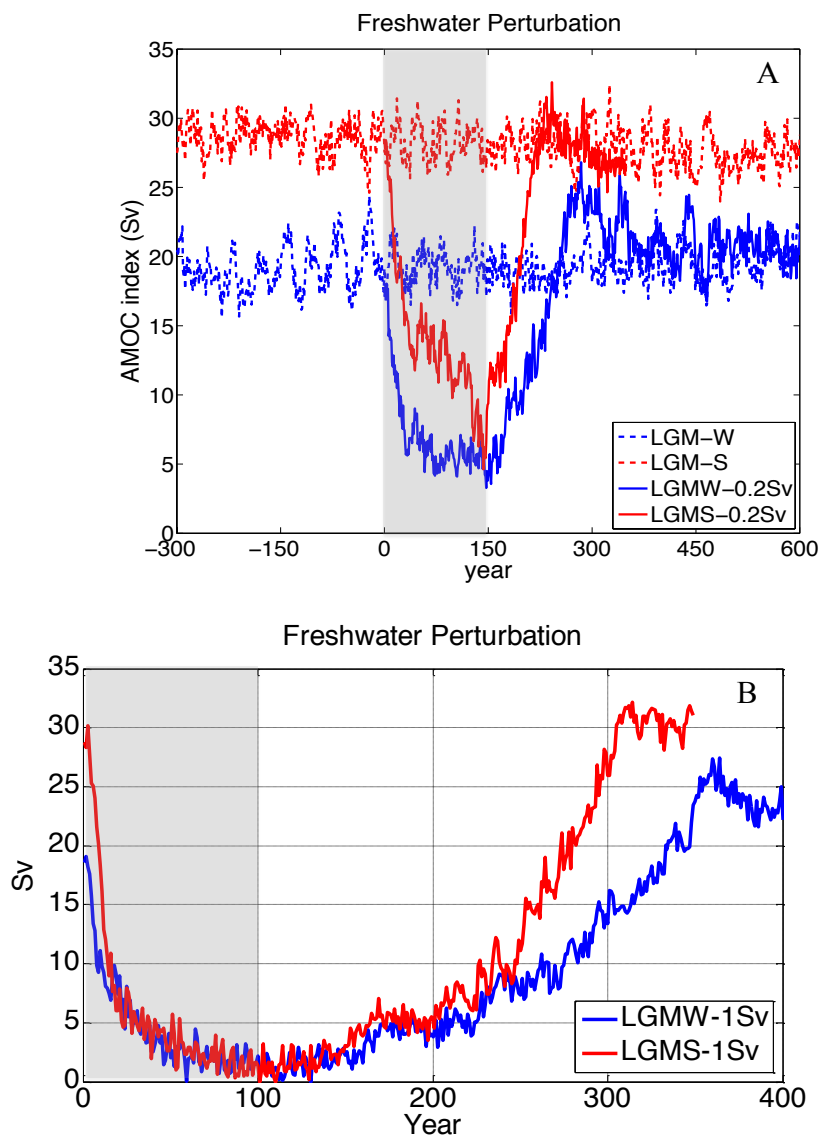

Fig. 8. Time series of AMOC in the $0.2 \mathrm{~Sv}$ (A: FWP lasts for $150 \mathrm{yr}$ ) and the $1 \mathrm{~Sv}$ (B: FWP lasts for $100 \mathrm{yr}$ ) hosing experiments LGMW-e (blue) and LGMS- $t_{\text {deep }}$ (red), respectively. The hosing experiments started from the model year 2700 in each LGM simulation. Dashed lines represent the LGM control runs (A), and solid lines the hosing experiments (A, B). Despite the different amount of FWP, a transition between the states LGMW-e and LGMS- $t_{\text {deep }}$ is not triggered. A robust overshoot of the AMOC is only detected in quasiequilibrium ocean states (see also Fig. S7).

(e.g. LGMS), the simulated ocean state after 2500 model years reaches a temporary quasi-equilibrium state identified by the PMIP protocol, in which the trends in the deep ocean are significant. (Figs. 2-4 and S1). The simulated surface properties are consistent with reconstructions (Figs. 5 and 6), further masking the transient deep ocean characteristics. This feature is not identified in the simulation initialized from a glacial ocean state (LGMW). Due to the lack of a specification regarding the initial ocean state for simulating the LGM, all the PMIP2 models (except CCSM3 and HadCM) were initialized from the present-day ocean (Braconnot et al., 2007; Weber et al., 2007). As a consequence, CCSM3 and $\mathrm{HadCM}$ eventually generate a glacial-like ocean (e.g. LGMW-e) as well as the AMOC overshoot after the FWP (e.g. in CCSM3, Cheng et al., 2011), whereas other simulations generate a present-day-like ocean (e.g. LGMS- $t_{\text {deep }}$ )

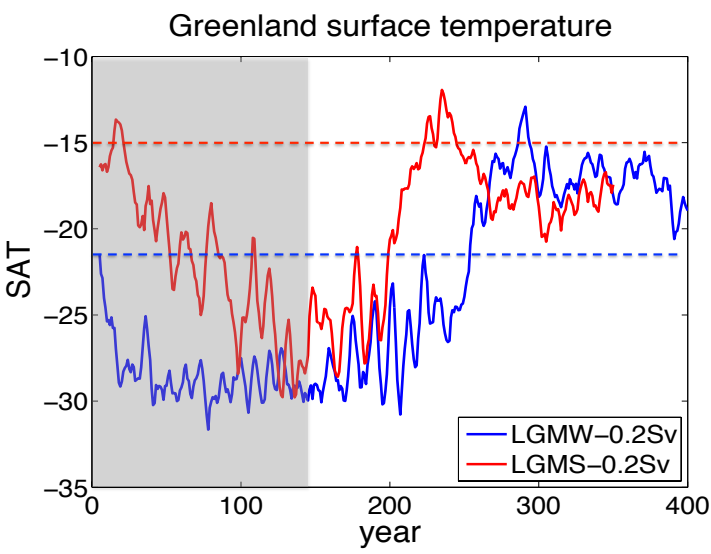

A

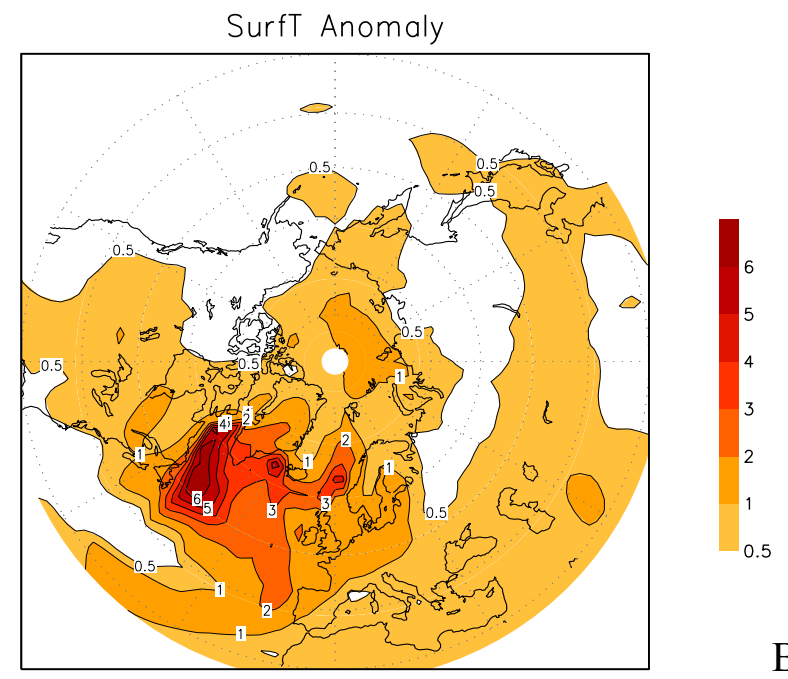

Fig. 9. (A) Surface air temperature (SAT) in the latitude belt of 60$70^{\circ} \mathrm{N}$ in the North Atlantic in LGMW-0.2Sv (blue) and LGMS$0.2 \mathrm{~Sv}$ (red). $5 \mathrm{yr}$ running mean was used to filter out the highfrequency signals of the SAT. The red and blue dashed lines indicate the pre-hosing reference level for LGMS- $t_{\text {deep }}$ and LGMW-e, respectively. (B) Excess surface temperature increase related to the overshoot of the AMOC (270th-300th yr) in LGMW-0.2Sv. The pronounced temperature increase relative to LGMW in the North Hemisphere is up to $6.8^{\circ} \mathrm{C}$ at convection sites in the Northern Atlantic.

without the feature of an AMOC overshoot (e.g. in ECBiltCLIO-VECODE, Roche et al., 2010), emphasizing the important role played by initial ocean states on LGM simulations (Figs. 1, 8 and 9). Furthermore, our results could be interpreted in the sense that the large spread of simulated LGM ocean state among the PMIP2 models can be attributed to different (or insufficient) deep ocean equilibration or initialization.

\subsubsection{Deep ocean quasi-equilibrium criteria}

It is noteworthy that the fundamental difference between LGM ocean states LGMW-e and LGMS- $t_{\text {deep }}$ is their distinct 
Zonal mean SST anomaly between PMIP2 models and WOA98

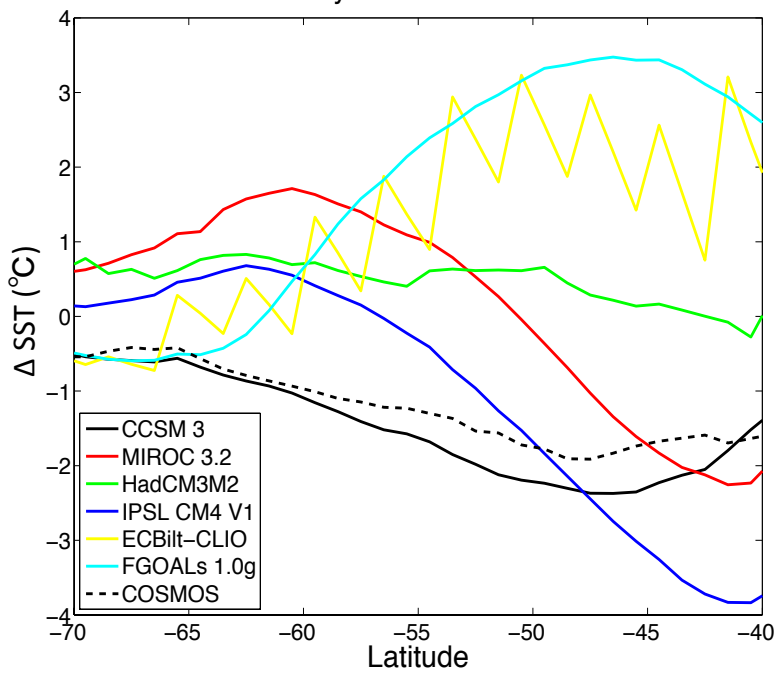

Fig. 10. Zonal mean of SST anomaly between respective PI control runs of the models participating in PMIP2 and observational data (World Ocean Atlas 98), i.e. CCSM3 (black solid), MIROC 3.2 (red solid), HadCM3M2 (green solid), IPSL-CM4-V1-MR (blue solid), ECBilt-CLIO (yellow solid), FGOALS-1.0g (cyan solid)), as well as the model used in this study (COSMOS, black dashed).

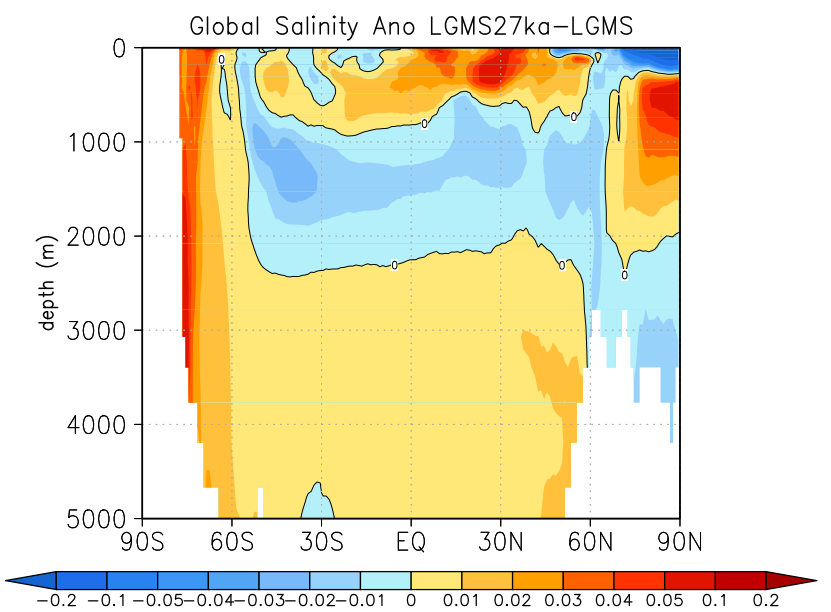

Fig. 11. Meridional section of zonal mean salinity anomalies (shaded) in global ocean between LGMS27ka and LGMS-e. For the comparison, we averaged the corresponding model year 4600-4700 in both experiments.

vertical stratification associated with the AABW-cell, which is relatively stable compared with the NADW-cell in the LGM simulations (Fig. 2). This is supposed to be the main cause for a weaker NADW-cell associated with a pronounced vertical stratification, owing to continuous transportation of the dense AABW to the abyssal Atlantic basin in LGMS. To explicitly diagnose the transient characteristics of the deep ocean in LGMS and qualify the possibility that the deep ocean in some of the PMIP2 models were not in quasi-
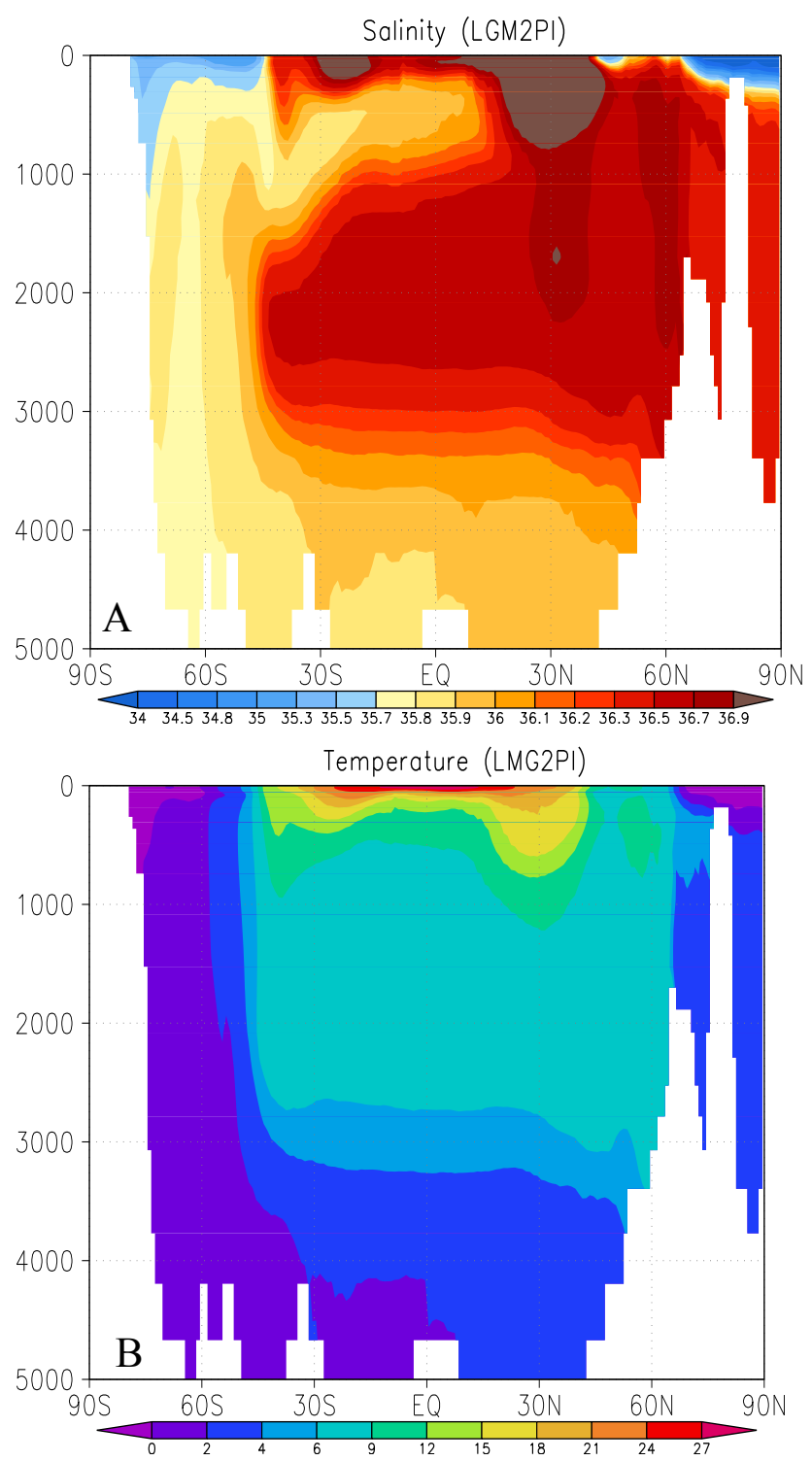

Fig. 12. Meridional section of zonal mean temperature (A) and salinity (B) in the Atlantic Ocean in LGM2PI. The deep ocean structure is similar to PI control run, indicating that the Pre-industrial simulation is insensitive to the initial ocean condition.

equilibrium, an equilibrium criteria for deep ocean properties should be well specified for future model inter-comparisons.

Shown in Fig. 4 are the salinity trends in the Atlantic Ocean in LGMS- $t_{\text {deep }}$, LGMS-e, LGMW-e and model years 3800-4000 of LGMW. In the quasi-equilibrium ocean states in LGMW and LGMS-e (Fig. 4b-d), salinity varies at a rate of no more than 0.006 psu century $^{-1}$ at a water depth lower than $3000 \mathrm{~m}$, whereas up to or even more than

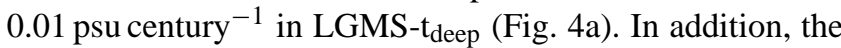
deep ocean salinity trend is relatively larger in the Atlantic section of the Southern Ocean that is one of main formation sites of AABW. Therefore, we propose that the glacial deep 


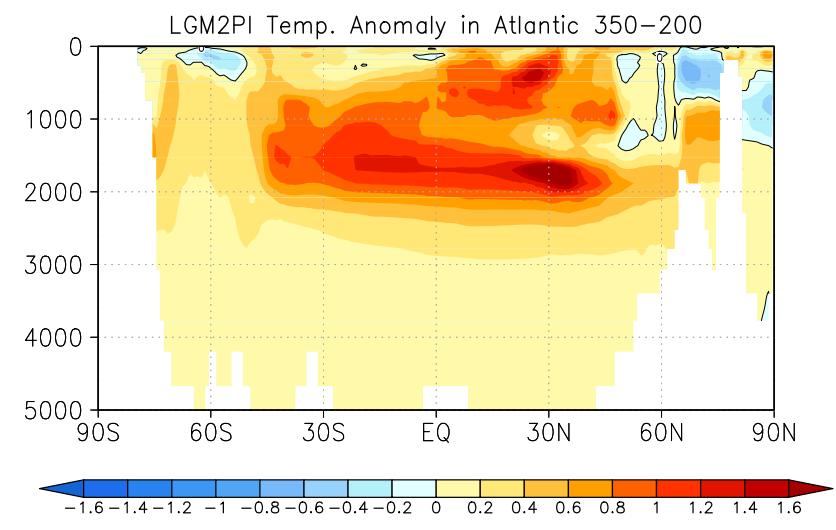

A

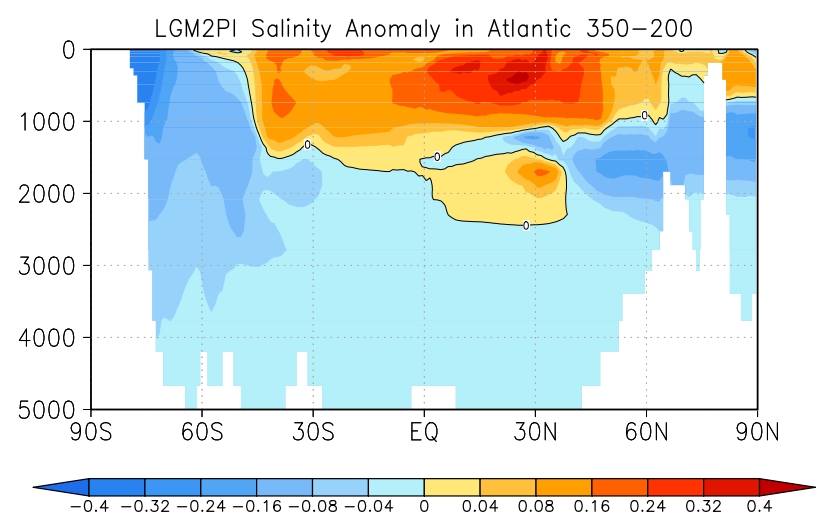

B

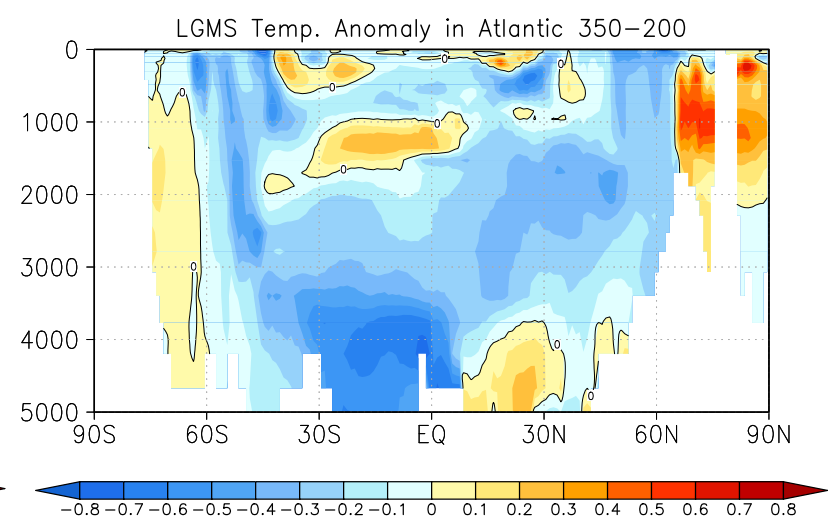

$\mathrm{C}$

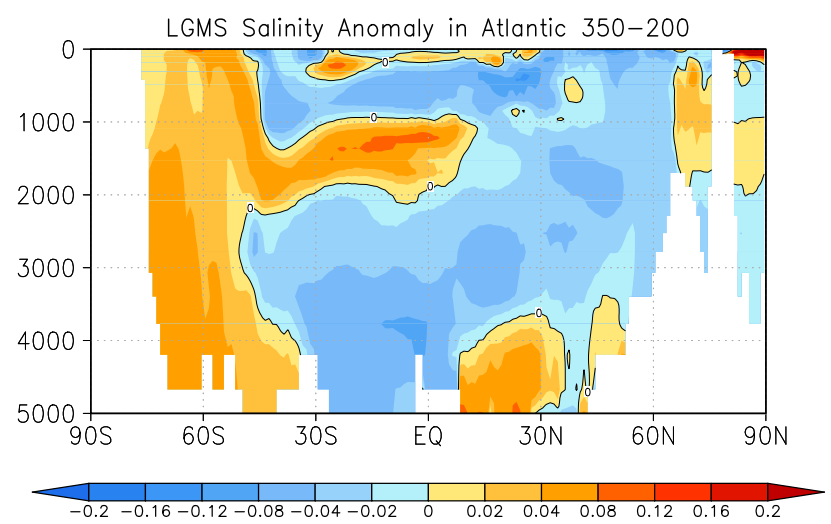

$\mathrm{D}$

Fig. 13. Zonal mean temperature (A, C) and salinity $(\mathbf{B}, \mathbf{D})$ anomalies between the 350th and 200th model year in LGM2PI (A, B) and LGMS (C, D). Note that the range of color bar in LGM2PI is twice as large as in LGMS.

ocean can be diagnosed as quasi-equilibrium at least when basin-wide average salinity at depths larger than $3000 \mathrm{~m}$ varies at a rate less than 0.006 psu century $^{-1}$ in Atlantic Ocean and less than 0.008 psu century $^{-1}$ in Atlantic section of Southern Ocean.

Previous model studies suggested that the strengthened sea ice formation and export under a cold climate could enhance brine rejection in the Southern Ocean, leading to a strengthened AABW (Shin et al., 2003; Butzin et al., 2005; Liu et al., 2005; Otto-Bliesner et al., 2007). This suggests that the colder the simulated Southern Ocean is, the more efficient the AABW formation. Figure 10 shows the zonal mean SST bias of the PMIP2 models with observation data at presentday. It is evident that only CCSM3 in the PMIP2 models and the model used in this study (COSMOS) have a general cooling bias south of $50^{\circ} \mathrm{S}$ that is close to the northern edge of winter sea ice cover during the LGM (Gersonde et al., 2005). This surface cooling bias may accelerate the formation of $\mathrm{AABW}$ and thus shorten the equilibrium timescale for the deep ocean. Considering the integration time of $5000 \mathrm{yr}$ in the simulation LGMS, we suggest that the equilibrium timescale for the PMIP2 models initialized from present-day ocean state could be no less than $5000 \mathrm{yr}$. Given the equilibrium timescale of $\sim 2500 \mathrm{yr}$ in LGMW, it is of utmost importance to specify one standard glacial ocean state to initialize the glacial simulations in the new phase of PMIP for the improvement of LGM simulations and future inter-model and model-data comparison.

\subsection{Potential origin of the glacial deep ocean}

Under the LGM ( $\sim 21 \mathrm{ka} \mathrm{BP})$ boundary conditions the simulated quasi-equilibrium ocean states starting from different initial ocean states in our climate model, i.e. LGMSe and LGMW-e, are comparable to reconstructions (Duplessy et al., 1988; Curry and Oppo, 2005; Marchitto and Broecker, 2006; Lynch-Stieglitz et al., 2007) (Figs. 5-7 and S2), however, the equilibrium timescale in the simulations initialized from the glacial ocean is only about half of the simulation initialized from the present-day ocean state. Reconstruction data indicates that $\delta^{13} \mathrm{C}$-depleted and nutrientrich water mass dominates the bottom of the Atlantic Ocean during the LGM, which is supposed to be a result from a 
northward invasion of AABW. However, it is worth noting that the nutrient proxy data cannot rule out that the reconstructed ocean structure during the LGM might have been formed prior to the LGM. Recently, Schmitt et al. (2012) suggested that the carbon cycle in the climate system during the LGM was already in an equilibrium and the net transfer of carbon to the deep ocean had occurred prior to the LGM. Additionally, in previous ocean model studies a glacial ocean comparable to the reconstructions can be generated only if sea ice export is imposed to the glacial Southern Ocean (Butzin et al., 2005; Hesse et al., 2011), suggesting that the deep-ocean water mass distribution as inferred from reconstructions is sensitive to the sea ice dynamics in the Southern Ocean. Using a sea ice reconstruction based on diatoms, Allen et al. (2011) suggested that more extensive sea ice extent was found between $\sim 22 \mathrm{ka}$ and $\sim 30 \mathrm{kaBP}$, overlapping with the minimum temperature in Antarctica that is attributed to the lowest obliquity-reducing annual mean solar radiation to high latitudes. This indicates that the brine rejection associated with sea ice formation might be stronger than during the LGM, resulting in a stronger AABW formation. Notably, there is also a sharp decrease of atmospheric $\mathrm{CO}_{2}$ concentration and benthic $\delta^{13} \mathrm{C}$ at the beginning of Marine Isotope Stage 2 (MIS2, $27 \mathrm{ka} \mathrm{BP}$ ) (e.g. Hodell et al., 2003; Ahn and Brook, 2008), implicating abrupt formation of an abyssal carbon reservoir. In addition, the northward invasion of enhanced $\mathrm{AABW}$, beginning at $\sim 27 \mathrm{ka} \mathrm{BP}$, also indicates the formation of the reconstructed LGM ocean structure (Gutjahr and Lippold, 2011) prior to the LGM. Accordingly, it is conceivable that the reconstructed water mass configuration during the LGM might stem from the inception of MIS2 ( $\sim 27 \mathrm{kaBP})$ that might be the onset of the last deglaciation due to the following Heinrich Event 2 and subsequent abrupt warming over Greenland (Hemming, 2004; Blunier and Brook, 2001) and slight increase of atmospheric $\mathrm{CO}_{2}$ concentration (Ahn and Brook, 2008). This hypothesis is supported by our LGM simulations and the hosing experiments, referring to its long-term equilibrium timescale from present-day ocean (about $5000 \mathrm{yr}$, even longer than the LGM) and distinct AMOC recovery processes to the FWP, respectively. In addition, model outputs from the simulation LGMS27ka further corroborate that the formation of AABW during $27 \mathrm{kaBP}$, as well as the AABW-cell are more expanded than during the LGM (Fig. 11), implying a critical role of the time interval, $27 \mathrm{kaBP}$, for the formation of the reconstructed LGM ocean structure (Duplessy et al., 1988; Curry and Oppo, 2005; Marchitto and Broecker, 2006) and the inception of the last deglaciation.

\subsection{Differences of deep ocean equilibrium timescales between PI and LGM conditions}

In the following we investigate whether the dependence of equilibrium timescales on initial ocean states is also present in PI simulations. Figure 12 shows the meridional sections of zonal mean sea salinity and temperature along Atlantic Ocean in simulation LGM2PI. The resulting deep ocean properties are similar to our PI control run (Fig. 12), implying the equilibrium timescale of the deep ocean under PI boundary conditions is shorter than under LGM conditions.

Shown in Fig. 13 are the changes of sea temperature and salinity with time during the spin-up of LGM2PI and LGMS. In the spin-up of the LGM2PI, the upper layers of the ocean are warmed due to the warm boundary conditions (Fig. 13a), reducing the AMOC and NADW formation (Fig. S11). In this case the way that the bottom water mass interacts with the surface is mainly through the AABW formation in the Southern Ocean. In our climate model the major regions of AABW formation in PI are Antarctic on-shore areas where brine rejection occurs (Fig. 13a, b) due to sea ice formation and export. Given this, the warm upper-layer water mass can be transported to the bottom in the Southern Ocean (Fig. 13a) and destabilizes the ocean stratification. Under LGM boundary conditions, the equatorward-extended permanent sea ice edge (Fig. 5) will shift the major AABW formation regions to the open ocean (Fig. 13c, d) where the dilution of the brines released by sea ice is more important and the effect of the brine-generated dense water is much more reduced than in on-shore regions (Bouttes et al., 2012). In addition, the cooled upper-layer water mass favors a strengthened AMOC during the spin-up of LGMS (Fig. S11), decelerating the northward extension of glacial AABW. Thus, the difference of the equilibrium timescale of deep ocean water mass between PI and LGM boundary conditions can be attributed to the shift of AABW formation sites and different responses of the AMOC to the boundary conditions during the spin-up.

\section{Summary and conclusions}

Based on our investigations of transient and quasiequilibrium integrations of the glacial and interglacial climate we find a suite of key findings and conclusions that can be summarized in the context of (A) time-dependent characteristics and (B) general implications.

(A) Time-dependent characteristics of ocean properties and the AMOC:

- Climatological surface characteristics can be similar and quasi-stationary, even when a significant trend in deep ocean properties still exists.

- According to the PMIP criteria (Braconnot et al., 2007), such quasi-stationary states can be classified as equilibrium states, based on surface temperature trend analysis. Hence, caution on deep ocean must be taken when these allegedly quasi-equilibrium states, on the basis of surface properties, are used as a reference for both model inter-comparison and data/model comparison. 
- The equilibrium timescale of the deep ocean in the LGM simulation initialized from present-day ocean might be in the order of $\sim 5000 \mathrm{yr}$, whereas only around $2500 \mathrm{yr}$ in the ocean initialized from a glacial ocean state.

- The equilibrium timescale under LGM boundary conditions $(\sim 5000 \mathrm{yr})$ is much longer than under preindustrial boundary conditions, most likely due to a less effective transfer of temperature and salinity changes to the abyssal ocean and different responses of the AMOC to boundary conditions during the spin-up.

- Hosing experiments suggest that the glacial ocean is mono-stable with respect to North Atlantic freshwater perturbations and that the AMOC response, especially with respect to overshoot, is modulated by the ocean stratification.

(B) Implications for data/model and inter-model differences and last deglaciation:

- Differences in the AMOC strength and deep ocean properties between quasi-equilibrium states suggest that the large spread among the modeled LGM ocean states and the apparent discrepancies in comparison to proxy data could be partly due to the dependency of equilibrium timescale of the deep ocean on the initial ocean states under glacial conditions. Thus, future protocols of PMIP might benefit from a detailed description of initialization procedures to warrant a sensible model inter-comparison, as well as data/model comparison

- The time prior to the LGM ( $\sim 27 \mathrm{ka} \mathrm{BP})$ is important for the formation of the LGM deep ocean characteristics (e.g. the salty glacial AABW), and changes in the glacial deep ocean might already occur before the last deglaciation.

- In paleocean modelling, glacial ocean states with significant trends in deep ocean might be improperly considered as equilibrium solutions to represent the simulated LGM climatology. This reflects the notion that, due to the transient nature of climate forcings, the real glacial (LGM) ocean state was in fact in a state of quasi-equilibrium.

\section{Supplementary material related to this article is available online at http://www.clim-past.net/9/2319/2013/ cp-9-2319-2013-supplement.pdf.}

Acknowledgements. We thank the colleagues in Paleoclimate Dynamics group in the Alfred Wegener Institute Helmholtz Centre for Polar and Marine Research (AWI) in Bremerhaven for useful discussions. Thanks to Conor Purcell for help with English, Stephan Hageman in the Max Plank Institute in Hamburg for the HD model and the computer center of the AWI for the help in running the AWI supercomputer. Furthermore thank the reviewers and editor for constructive comments to improve the manuscript. $X$. Zhang was funded by China Scholarship Council (CSC). $\mathrm{X}$. Zhang and G. Lohmann are funded through the PACES program of the AWI in the Helmholtz society in Germany. G. Knorr is funded by REKLIM. Thanks go furthermore to the Max Planck Institute in Hamburg (Germany) making the COSMOS model available to us and scientists in the PMIP for providing us with their data.

Edited by: V. Rath

\section{References}

Adkins, J. F., McIntyre, K., and Schrag, D. P.: The salinity, temperature, and delta18O of the glacial deep ocean, Science, 298, 1769-1773, doi:10.1126/science.1076252, 2002.

Ahn, J. and Brook, E. J.: Atmospheric $\mathrm{CO}_{2}$ and climate on millennial time scales during the last glacial period, Science, 83, 83-85, doi:10.1126/science.1160832, 2008.

Allen, C. S., Pike, J., and Pudsey, C. J.: Last glacial-interglacial sea-ice cover in the SW Atlantic and its potential role in global deglaciation, Quaternary Sci. Rev., 30, 2446-2458, doi:10.1016/j.quascirev.2011.04.002, 2011.

Bard, E., Rostek, F., Turon, J., and Gendreau, S.: Hydrological impact of heinrich events in the subtropical northeast atlantic, Science, 289, 1321-1324, 2000.

Barker, S., Knorr, G., Vautravers, M. J., Diz, P., and Skinner, L. C.: Extreme deepening of the Atlantic overturning circulation during deglaciation, Nat. Geosci., 3, 567-571, doi:10.1038/ngeo921, 2010.

Blunier, T. and Brook, E. J.: Timing of Millennial-Scale Climate Change in Antarctica and Greenland During the Last Glacial Period, Science, 291, 109-112, doi:10.1126/science.291.5501.109, 2001.

Bouttes, N., Paillard, D., Roche, D. M., Waelbroeck, C., Kageyama, M., Lourantou, A., Michel, E., and Bopp, L.: Impact of oceanic processes on the carbon cycle during the last termination, Clim. Past, 8, 149-170, doi:10.5194/cp-8-149-2012, 2012.

Braconnot, P., Otto-Bliesner, B., Harrison, S., Joussaume, S., Peterchmitt, J. Y., Abe-Ouchi, A., Crucifix, M., Driesschaert, E., Fichefet, T., Hewitt, C. D., Kageyama, M., Kitoh, A., Laine, A., Loutre, M. F., Marti, O., Merkel, U., Ramstein, G., Valdes, P., Weber, S. L., Yu, Y., and Zhao, Y.: Results of PMIP2 coupled simulations of the Mid-Holocene and Last Glacial Maximum \&ndash; Part 1: experiments and large-scale features, Clim. Past, 3, 261-277, doi:10.5194/cp-3-261-2007, 2007.

Braconnot, P., Harrison, S. P., Kageyama, M., Bartlein, P. J., Masson-Delmotte, V., Abe-Ouchi, A., Otto-Bliesner, B., and Zhao, Y.: Evaluation of climate models using palaeoclimatic data, Nat. Clim. Change, 2, 417-424, 2012.

Brovkin, V., Raddatz, T., Reick, C. H., Claussen, M., and Gayler, V.: Global biogeophysical interactions between forest and climate, Geophys. Res. Lett., 36, 1-5, doi:10.1029/2009GL037543, 2009. 
Butzin, M., Prange, M., and Lohmann, G.: Radiocarbon simulations for the glacial ocean: The effects of wind stress, Southern Ocean sea ice and Heinrich events, Earth Planet. Sci. Lett., 235, 45-61, doi:10.1016/j.epsl.2005.03.003, 2005.

Cheng, J., Liu, Z., He, F., Otto-Bliesner, B. L., Brady, E. C., and Wehrenberg, M.: Simulated Two-Stage Recovery of Atlantic Meridional Overturning Circulation During the Last Deglaciation, in: Abrupt Climate Change: Mechanisms, Patterns, and Impacts, American Geophysical Union, 75-92, 2011.

Clark, P. U., Dyke, A. S., Shakun, J. D., Carlson, A. E., Clark, J., Wohlfarth, B., Mitrovica, J. X., Hostetler, S. W., and McCabe, A. M.: The Last Glacial Maximum, Science, 325, 710714, doi:10.1126/science.1172873, 2009.

CLIMAP Project Members.: Seasonal reconstruction of the earth's surface at the last glacial maximum, Geological Society of America Map and Chart Series, MC-36, 17, 1981.

Crucifix, M., Braconnot, P., Harrison, S. P., and Otto-Bliesner, B.: Second phase of paleoclimate modelling intercomparison project, Eos, Transactions American Geophysical Union, 86, 264-264, doi:10.1029/2005eo280003, 2005.

Curry, W. B. and Oppo, D.: Glacial water mass geometry and the distribution of $\delta^{13} \mathrm{C}$ of $\Sigma \mathrm{CO}_{2}$ in the western Atlantic Ocean, Paleoceanography, 20, 1-13, doi:10.1029/2004PA001021, 2005.

Dansgaard, W., Johnsen, S. J., Clausen, H. B., Dahl-Jensen, D., Gundestrup, N. S., Hammer, C. U., Hvidberg, C. S., Steffensen, J. P., Sveninbjoernsdottir, A. E., Jouzel, J., and Bond, G.: Evidence for general instability of past climate from a 250-kyr ice-core record, Nature, 364, 218-220, 1993.

de Vernal, A., Rosell-Melé, A., Kucera, M., Hillaire-Marcel, C., Eynaud, F., Weinelt, M., Dokken, T., and Kageyama, M.: Comparing proxies for the reconstruction of LGM sea-surface conditions in the northern North Atlantic, Quaternary Sci. Rev., 25, 28202834, doi:10.1016/j.quascirev.2006.06.006, 2006.

de Vries, P. and Weber, S. L.: The Atlantic freshwater budget as a diagnostic for the existence of a stable shut down of the meridional overturning circulation, Geophys. Res. Lett., 32, 1-4, doi:10.1029/2004GL021450, 2005.

Dowsett, H. J., Foley, K. M., Stoll, D. K., Chandler, M. A., Sohl, L. E., Bentsen, M., Otto-Bliesner, B. L., Bragg, F. J., Chan, W.-L., Contoux, C., Dolan, A. M., Haywood, A. M., Jonas, J. A., Jost, A., Kamae, Y., Lohmann, G., Lunt, D. J., Nisancioglu, K. H., Abe-Ouchi, A., Ramstein, G., Riesselman, C. R., Robinson, M. M., Rosenbloom, N. A., Salzmann, U., Stepanek, C., Strother, S. L., Ueda, H., Yan, Q., and Zhang, Z.: Sea Surface Temperature of the mid-Piacenzian Ocean: A Data-Model Comparison, Sci. Rep., 3, 2013, doi:10.1038/srep02013, 2013.

Duplessy, J. C., Shackleton, N. J., Fairbanks, R. G., Labeyriefi, L., Oppo, D., and Kallel, N.: Deepwater Source Variations during the Last Climatic Cycle and Their impact on the Global Deepwater Circulation, Paleoceanography, 3, 343-360, 1988.

Ganachaud, A. and Wunsch, C.: Improved estimates of global ocean circulation, heat transport and mixing from hydrographic data, Nature, 408, 453-457, doi:10.1038/35044048, 2000.

Ganopolski, A. and Rahmstorf, S.: Rapid changes of glacial climate simulated in a coupled climate model, Nature, 409, 153158, doi:10.1038/35051500, 2001.

Gersonde, R., Crosta, X., Abelmann, A., and Armand, L.: Sea-surface temperature and sea ice distribution of the Southern Ocean at the EPILOG Last Glacial Maxi- mum - a circum-Antarctic view based on siliceous microfossil records, Quaternary Sci. Rev., 24, 869-896, doi:10.1016/j.quascirev.2004.07.015, 2005.

Gherardi, J. M., Labeyrie, L., Nave, S., Francois, R., McManus, J. F., and Cortijo, E.: Glacial-interglacial circulation changes inferred from $231 \mathrm{~Pa} / 230 \mathrm{Th}$ sedimentary record in the North Atlantic region, Paleoceanography, 24, 1-14, doi:10.1029/2008PA001696, 2009.

Gong, X., Knorr, G., Lohmann, G., and Zhang, X.: Dependence of abrupt Atlantic meridional ocean circulation changes on climate background states, Geophys. Res. Lett., 40, 3698-3704, doi:10.1002/grl.50701, 2013.

Gordon, C., Cooper, C., Senior, C. A., Banks, H., Gregory, J. M., Johns, T. C., Mitchell, J. F. B., and Wood, R. A.: The simulation of SST, sea ice extents and ocean heat transports in a version of the Hadley Centre coupled model without flux adjustments, Clim. Dynam., 16, 147-168, doi:10.1007/s003820050010, 2000.

Gutjahr, M. and Lippold, J.: Early arrival of Southern Source Water in the deep North Atlantic prior to Heinrich event 2, Paleoceanography, 26, 1-9, doi:10.1029/2011PA002114, 2011.

Hagemann, S.: An improved land surface parameter dataset for global and regional climate models. Report 336, Max-PlanckInstitut fuer Meteorologie, Hamburg, 2002.

Hemming, S.: Heinrich Events: Massive Late Pleistocene Detritus Layers of the North Atlantic and their global Climate Imprint, Rev. Geophys., 42, RG1005, doi:10.1029/2003RG000128, 2004.

Hesse, T., Butzin, M., Bickert, T., and Lohmann, G.: A model-data comparison of $\delta^{13} \mathrm{C}$ in the glacial Atlantic Ocean, Paleoceanography, 26, PA3220, doi:10.1029/2010PA002085, 2011.

Hibler III, W.: A dynamic thermodynamic sea ice model, J. Phys. Oceanogr., 9, 815-846, 1979.

Hodell, D. A., Venz, K. A., Charles, C. D., and Ninneman, U. S.: Pleistocene vertical carbon isotope and carbonate gradients in the South Atlantic sector of the Southern Ocean, Geochem. Geophys. Geosyst., 4, 1004, doi:10.1029/2002GC000367, 2003.

Huybers, P. and Wunsch, C.: Paleophysical Oceanography with an Emphasis on Transport Rates, Ann. Rev. Mar. Sci., 2, 1-34, doi:10.1146/annurev-marine-120308-081056, 2010.

Jungclaus, J. H., Lorenz, S. J., Timmreck, C., Reick, C. H., Brovkin, V., Six, K., Segschneider, J., Giorgetta, M. A., Crowley, T. J., Pongratz, J., Krivova, N. A., Vieira, L. E., Solanki, S. K., Klocke, D., Botzet, M., Esch, M., Gayler, V., Haak, H., Raddatz, T. J., Roeckner, E., Schnur, R., Widmann, H., Claussen, M., Stevens, B., and Marotzke, J.: Climate and carbon-cycle variability over the last millennium, Clim. Past, 6, 723-737, doi:10.5194/cp-6723-2010, 2010.

K-1-Model-Developers: K-1 Coupled GCM (MIROC Description) 1, 34 pp., 2004.

Kageyama, M., Merkel, U., Otto-Bliesner, B., Prange, M., AbeOuchi, A., Lohmann, G., Ohgaito, R., Roche, D. M., Singarayer, J., Swingedouw, D., and Zhang, X.: Climatic impacts of fresh water hosing under Last Glacial Maximum conditions: a multimodel study, Clim. Past, 9, 935-953, doi:10.5194/cp-9-9352013, 2013.

Knorr, G. and Lohmann, G.: Southern Ocean origin for the resumption of Atlantic thermohaline circulation during deglaciation, Nature, 424, 532-536, doi:10.1038/nature01855, 2003.

Knorr, G. and Lohmann, G.: Rapid transitions in the Atlantic thermohaline circulation triggered by global warming and meltwater 
during the last deglaciation, Geochem. Geophys. Geosyst., 8, Q12006, doi:10.1029/2007GC001604, 2007.

Knorr, G., Butzin, M., Micheels, A., and Lohmann, G.: A warm Miocene climate at low atmospheric $\mathrm{CO}_{2}$ levels, Geophys. Res. Lett., 38, 1-5, doi:10.1029/2011GL048873, 2011.

Kucera, M., Weinelt, M., Kiefer, T., Pflaumann, U., Hayes, A., Weinelt, M., Chen, M.-T., Mix, A. C., Barrows, T. T., Cortijo, E., Duprat, J., Juggins, S., and Waelbroeck, C.: Reconstruction of sea-surface temperatures from assemblages of planktonic foraminifera: multi-technique approach based on geographically constrained calibration data sets and its application to glacial Atlantic and Pacific Oceans, Quaternary Sci. Rev., 24, 951-998, doi:10.1016/j.quascirev.2004.07.014, 2005.

Laskar, J., Robutel, P., Joutel, F., Gastineau, M., Correia, A. C. M., and Levrard, B.: A long-term numerical solution for the insolation quantities of the Earth, A\&A, 428, 261-285, 2004.

Lea, D. W., Pak, D. K., Peterson, L. C., and Hughen, K. A.: Synchroneity of tropical and high-latitude Atlantic temperatures over the last glacial termination, Science, 301, 1361-1364, doi:10.1126/science.1088470, 2003.

LeGrand, P., and Wunsch, C.: Constraints from Paleotracer Data on the North Atlantic Circulation During the Last Glacial Maximum, Paleoceanography, 10, 1011-1045, doi:10.1029/95pa01455, 1995.

Levitus, S., Boyer, T. P., Conkright, M. E., O’Brien, T., Antonov, J., Stephens, C., Stathoplos, L., Johnson, D., and Gelfeld, R.: NOAA Atlas NESDIS 18, World Ocean Database 1998: Volume 1: Introduction, US Gov. Printing Office, Washington D.C., 346 pp., 1998.

Lippold, J., Luo, Y., Francois, R., Allen, S. E., Gherardi, J., Pichat, S., Hickey, B., and Schulz, H.: Strength and geometry of the glacial Atlantic Meridional Overturning Circulation, Nat. Geosci., 5, 813-816, 2012.

Liu, Z., Shin, S.-I., Webb, R. S., Lewis, W., and Otto-Bliesner, B. L.: Atmospheric $\mathrm{CO}_{2}$ forcing on glacial thermohaline circulation and climate, Geophys. Res. Lett., 32, L02706, doi:10.1029/2004g1021929, 2005.

Liu, Z., Otto-Bliesner, B. L., He, F., Brady, E. C., Tomas, R., Clark, P. U., Carlson, A. E., Lynch-Stieglitz, J., Curry, W., Brook, E., Erickson, D., Jacob, R., Kutzbach, J., and Cheng, J.: Transient simulation of last deglaciation with a new mechanism for Bolling-Allerod warming, Science, 325, 310-314, doi:10.1126/science.1171041, 2009.

Lohmann, G. and Lorenz, S.: On the hydrological cycle under paleoclimatic conditions as derived from AGCM simulations, J. Geophys. Res.-Atmos., 105, 17417-17436, doi:10.1029/2000jd900189, 2000.

Lynch-Stieglitz, J., Adkins, J. F., Curry, W. B., Dokken, T., Hall, I. R., Herguera, J. C., Hirschi, J. J.-M., Ivanova, E. V., Kissel, C., Marchal, O., Marchitto, T. M., McCave, I. N., McManus, J. F., Mulitza, S., Ninnemann, U., Peeters, F., Yu, E.-F., and Zahn, R.: Atlantic meridional overturning circulation during the Last Glacial Maximum, Science. 316, 66-69, doi:10.1126/science.1137127, 2007.

Marti, O., Braconnot, P., Bellier, J., Benshila, R., Bony, S., Brockmann, P., Cadule, P., Caubel, A., Denvil, S., Dufresne, J.-L., Fairhead, L., Filiberti, M.-A., Foujols, M.-A., Fichefet, T., Friedlingstein, P., Goosse, H., Grandpeix, J.-Y., Hourdin, F., Krinner, G., Lévy, C., Madec, G., Musat, I., de Noblet, N., Polcher, J., and
Talandier, C.: The new IPSL climate system model: IPSL-CM4, Paris, Institut Pierre Simon Laplace: 84, 2005.

Manabe, S. and Stouffer, R. J.: Two stable equilibria of a coupled ocean-atmosphere model, J. Climate, 1, 841-866, 1988.

Marchitto, T. M. and Broecker, W. S.: Deep water mass geometry in the glacial Atlantic Ocean: A review of constraints from the paleonutrient proxy $\mathrm{Cd} / \mathrm{Ca}$, Geochem. Geophys. Geosyst., 7, Q12003, doi:10.1029/2006GC001323, 2006.

Marsland, S. J., Haak, H., Jungclaus, J. H., Latif, M., and Röske, F.: The Max-Planck-Institute global ocean/sea ice model with orthogonal curvilinear coordinates, Ocean Modell., 5, 91-127, doi:10.1016/S1463-5003(02)00015-X, 2003.

McCave, I. N., Manighetti, B., and Beveridge, N. A. S.: Circulation in the glacial North Atlantic inferred from grain-size measurements, Nature, 374, 149-152, 1995.

McManus, J. F., Francois, R., Gherardi, J.-M., Keigwin, L. D., and Brown-Leger, S.: Collapse and rapid resumption of Atlantic meridional circulation linked to deglacial climate changes, $\mathrm{Na}-$ ture, 428, 834-837, doi:10.1038/nature02494, 2004.

Meehl, G. A., Stocker, T. F., Collins, W. D., Friedlingstein, P., Gaye, A. T., Gregory, J. M., Kitoh, A., Knutti, R., Murphy, J. M., Noda, A., Raper, S. C. B., Watterson, I. G., Weaver, A. J., and Zhao, Z.-C.: Global Climate Projections in: Climate Change 2007: The Physical Science Basis. Contribution of Working Group I to the Fourth Assessment Report of the Intergovernmental Panel on Climate Change, Methods, 747-845, 2007.

Menviel, L., Timmermann, A., Timm, O. E., and Mouchet, A.: Deconstructing the Last Glacial termination: the role of millennial and orbital-scale forcings, Quaternary Sci. Rev., 30, 1155-1172, doi:10.1016/j.quascirev.2011.02.005, 2011.

Mignot, J., Ganopolski, A., and Levermann, A.: Atlantic Subsurface Temperatures: Response to a Shutdown of the Overturning Circulation and Consequences for Its Recovery, Journal of Climate, 20, 4884-4898, doi:10.1175/JCLI4280.1, 2007.

Nakamura, M., Stone, P. H., and Marotzke, J.: Destabilization of the Thermohaline Circulation by Atmospheric Eddy Transports, J. Climate, 7, 1870-1882, doi:10.1175/15200442(1994)007<1870:dottcb>2.0.co;2, 1994.

Otto-Bliesner, B. L., Hewitt, C. D., Marchitto, T. M., Brady, E., Abe-Ouchi, A., Crucifix, M., Murakami, S., and Weber, S. L.: Last Glacial Maximum ocean thermohaline circulation: PMIP2 model intercomparisons and data constraints, Geophys. Res. Lett., 34, L12706, doi:10.1029/2007GL029475, 2007.

Paul, A. and Schäfer-Neth, C.: Modeling the water masses of the Atlantic Ocean at the Last Glacial Maximum, Paleoceanography, 18, 1058, doi:10.1029/2002PA000783, 2003.

Peltier, W. R.: GLOBAL GLACIAL ISOSTASY AND THE SURFACE OF THE ICE-AGE EARTH: The ICE-5G (VM2) Model and GRACE, An. Rev. Earth Planet. Sci., 32, 111-149, doi:10.1146/annurev.earth.32.082503.144359, 2004.

Pflaumann, U.: Glacial North Atlantic: Sea-surface conditions reconstructed by GLAMAP 2000, Paleoceanography, 18, 1065, doi:10.1029/2002PA000774, 2003.

Praetorius, S. K., McManus, J. F., Oppo, D. W., and Curry, W. B.: Episodic reductions in bottom-water currents since the last ice age, Nat. Geosci., 1, 449-452, doi:10.1038/ngeo227, 2008.

Rahmstorf, S., Crucifix, M., Ganopolski, A., Goosse, H., Kamenkovich, I., Knutti, R., Lohmann, G., Marsh, R., Mysak, L. A., Wang, Z., and Weaver, A. J.: Thermohaline circulation 
hysteresis: A model intercomparison, Geophys. Res. Lett., 32, L23605, doi:10.1029/2005GL023655, 2005.

Ritz, S. P., Stocker, T. F., Grimalt, J. O., Menviel, L., and Timmermann, A.: Estimated strength of the Atlantic overturning circulation during the last deglaciation, Nat. Geosci., 6, 208-212, 2013.

Roche, D., Wiersma, A., and Renssen, H.: A systematic study of the impact of freshwater pulses with respect to different geographical locations, Clim. Dynam., 34, 997-1013, doi:10.1007/s00382009-0578-8, 2010.

Roeckner, E., Baeuml, G., Bonaventura, L., Brokopf, R., Esch, M., Giorgetta, M., Hagemann, S., Kirchner, I., Kornblueh, L., Manzini, E., Rhodin, A., Schlese, U., Schulzweida, U., Tompkins, A., The atmospheric general circulation model ECHAM5. Part I: Model description, Planck Institute for Meteorology Rep., 349, $131 \mathrm{pp}$.

Schmitt, J., Schneider, R., Elsig, J., Leuenberger, D., Lourantou, A., Chappellaz, J., Köhler, P., Joos, F., Stocker, T. F., Leuenberger, M., and Fischer, H.: Carbon Isotope Constraints on the Deglacial $\mathrm{CO}_{2}$ Rise from Ice Cores, Science, 336, 711-714, doi:10.1126/science.1217161, 2012.

Shin, S. I., Liu, Z. G., Otto-Bliesner, B. L., Kutzbach, J. E., and Vavrus, S. J.: Southern Ocean sea-ice control of the glacial North Atlantic thermohaline circulation, Geophys. Res. Lett., 30, 1096, 2003.

Stepanek, C. and Lohmann, G.: Modelling mid-Pliocene climate with COSMOS, Geosci. Model Dev., 5, 1221-1243, doi:10.5194/gmd-5-1221-2012, 2012.

Stommel, H.: Thermohaline convection with two stable regimes of flow, Tellus, 13, 224-230, 1961.

Toggweiler, J. R. and Samuels, B.: Effect of Drake Passage on the global thermohaline circulation, Deep Sea Res. I, 42, 477-500, 1995.

Varma, V., Prange, M., Merkel, U., Kleinen, T., Lohmann, G., Pfeiffer, M., Renssen, H., Wagner, A., Wagner, S., and Schulz, M.: Holocene evolution of the Southern Hemisphere westerly winds in transient simulations with global climate models, Clim. Past, 8, 391-402, doi:10.5194/cp-8-391-2012, 2012.
Waelbroeck, C., Paul, A., Kucera, M., Rosell-Melé, A., Weinelt, M., Schneider, R., Mix, A. C., Abelmann, A., Armand, L., Bard, E., Barker, S., Barrows, T. T., Benway, H., Cacho, I., Chen, M.T., Cortijo, E., Crosta, X., de Vernal, A., Dokken, T., Duprat, J., Elderfield, H., Eynaud, F., Gersonde, R., Hayes, A., Henry, M., Hillaire-Marcel, C., Huang, C.-C., Jansen, E., Juggins, S., Kallel, N., Kiefer, T., Kienast, M., Labeyrie, L., Leclaire, H., Londeix, L., Mangin, S., Matthiessen, J., Marret, F., Meland, M., Morey, A. E., Mulitza, S., Pflaumann, U., Pisias, N. G., Radi, T., Rochon, A., Rohling, E. J., Sbaffi, L., Schäfer-Neth, C., Solignac, S., Spero, H., Tachikawa, K., and Turon, J.-L.: Constraints on the magnitude and patterns of ocean cooling at the Last Glacial Maximum, Nat. Geosci., 2, 127-132, doi:10.1038/ngeo411, 2009.

Weber, S. L., Drijfhout, S. S., Abe-Ouchi, A., Crucifix, M., Eby, M., Ganopolski, A., Murakami, S., Otto-Bliesner, B., and Peltier, W. R.: The modern and glacial overturning circulation in the Atlantic ocean in PMIP coupled model simulations, Clim. Past, 3, 51-64, doi:10.5194/cp-3-51-2007, 2007.

Wei, W. and Lohmann, G.: Simulated Atlantic Multidecadal Oscillation during the Holocene, J. Climate, 25, 6989-7002, doi:10.1175/jcli-d-11-00667.1, 2012.

Wei, W., Lohmann, G., and Dima, M.: Distinct modes of internal variability in the Global Meridional Overturning Circulation associated with the Southern Hemisphere westerly winds, J. Phys. Oceanogr., 42, 785-801, doi:10.1175/JPO-D-11-038.1, 2012.

Yu, Y., Yu, R., Zhang, X., and Liu, H.: A flexible coupled oceanatmosphere general circulation model, Adv. Atmos. Sci., 19, 169-190, doi:10.1007/s00376-002-0042-8, 2002.

Yu, Y., Zhang, X., and Guo, Y.: Global coupled ocean-atmosphere general circulation models in LASG/IAP, Adv. Atmos. Sci., 21, 444-455, doi:10.1007/bf02915571, 2004. 